\title{
Notes
}

\section{"DID I MISS ANYTHING?": EXCISING THE NATIONAL SECURITY COUNCIL FROM FOIA COVERAGE ${ }^{1}$}

\author{
R. KEVIN BAILEY \\ INTRODUCTION
}

Several weeks prior to the 1996 presidential election, the New York Times published a one-column story about a set of documents that the government had recently declassified. The article described the culmination of a lengthy effort on the part of historian Stanley I. Kutler to gain access to tapes and memoranda from the darkest days of President Richard Nixon's administration. ${ }^{2}$ This collection contained many gems, including a mennorandum written by Nixon in which the President related a description by his aide Donald Rumsfeld of the then-chair of the Republican National Committee, Bob Dole. The aide pointedly observed that Dole had lost "soine of his effectiveness because he is a 'kneejerk' defender of the Administration."3 Based at least in part on Rumsfeld's criticism of Dole's unnuanced defense of the administration, Nixon concluded that Dole should be removed from the chairmanship of the Republican Party and subsequently dismissed him. ${ }^{4}$ The irony: Donald Rumsfeld served as Dole's national campaign coordinator for the 1996 election. ${ }^{5}$

These Nixon documents have been sequestered from public view since the early 1970 s. $^{6}$ The National Archives only released

1. The author acknowledges the Honorable Michael Daly Hawkins, United States Court of Appeals for the Ninth Circuit, for his suggestion of the title. The noted phrase within it was spoken by Lt. Col. Ohver North in his testimony before Congress during the Iran-Contra investigation, in response to a question regarding whether he had shredded all documents related to the affair.

2. See Tim Weiner, Nixon Memo Criticizes Dole Defenses as 'Knee Jerk', N.Y. TIMES, Oct. 18, 1996, at A24. The National Archives released more than 28,000 documents generated by the Nixon administration in October of 1996 and over 200 hours of the President's audio tapes in November of that year. See id.

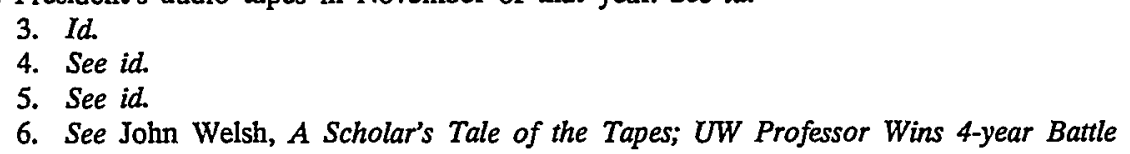


them after a lengthy battle waged under the auspices of the Freedom of Information Act (FOIA). ${ }^{7}$ The dispute over whether the documents and tapes would be released began in the late $1980 \mathrm{~s}^{8}$ and culminated with Kutler's 1992 lawsuit, ${ }^{9}$ which was finally settled last year. ${ }^{10}$ However, the released tapes only scratch the surface of the Archives' Nixon holdings. ${ }^{11}$ Kutler remained "mystified" as to why only soine of the "special files" were released while others remained classified. ${ }^{12}$ That ineluctable "mystery"-why some information is released to the public while other documents are redacted or retained in secret by the government-fuels the debate over the purpose and implementation of FOIA.

While Kutler's story reflects FOIA's impact on the Watergate imbroglio, another 1996 FOIA development concerned the Iran-

to Hear Nixon's Desperate Talk, WIS. ST. J., Dec. 8, 1996, at 1A. Nixon sought to block release of the documents and tapes, see Corrections, N.Y. TIMES, Oct. 19, 1996, at A2, and he succeeded in doing so for twenty years after his resignation.

7. 5 U.S.C. $\$ 552$ (1994).

8. See Weiner, supra note 2, at A24.

9. See Neil A. Lewis, In Newly Released Tapes, Nixon is Heard Grasping for Reas. surance, N.Y. TMMES, Nov. 19, 1996, at A21.

10. See Weiner, supra note 2 , at A24. Kutler believed that the true reason for the delay was the unflagging battle waged by Nixon to keep the tapes from becoming public: "The bottom tine in all this was as long as Richard Nixon breathed any air, we would not see any tapes." Welsh, supra note 6, at 1A. When Nixon died in 1994, the door opened for the Archives to comply with Kutler's request; it eventually agreed to do so. See Corrections, supra note 6 , at A2.

11. Weiner's article concludes with Kutler's observation that former White House Chief of Staff H.R. Haldeman's notes "provided a tantalizing preview for some 201 hours of Nixon White House tapes." Weiner, supra note 2, at A24. These tapes were released on November 18, 1996. See Lewis, supra note 9, at A21; see also ABC World News To. night ( $\mathrm{ABC}$ television broadcast, Nov. 18, 1996) (commentary by Barry Serafin) (chronicling the history of Nixon's abuse of power and the fascination that surrounds his actions).

12. Weiner, supra note 2, at A24. A possible explanation for the non-release of some inaterials is the distinction that the National Archives has tried to draw between political and governmental documents. See Jack N. Carl, Letter to the Editor, Nixon Papers, L.A. TIMES, Oct. 31, 1996, at B8 (lamenting this attempted distinction and observing that "[p]olitics and government are mutually inclusive"); see also Nixon Told Kissinger of Secret Tapings, Archives Papers Show, L.A. TDMES, Oct. 18, 1996, at A13 (quoting scholarly opinion that many documents were not released by the Archives because they were deemed "political rather than governmental"). The Archives subsequently announced that the tapes would be released in their entirety over a period of years, with the next group due in 1998. See Welsh, supra note 6, at 1A. No further information is available about the administrative papers which accompany the tapes and which were not among the 28,000 documents first inade available on October 17, 1996. See Carl, supra, at B8. 
Contra scandal of the mid-1980s. In Armstrong v. Executive Office of the President, ${ }^{13}$ the Court of Appeals for the District of Columbia Circuit reached a holding of crucial significance regarding the obhigations of the National Security Council (NSC) under FOIA. In an opinion by Judge Douglas Ginsburg, the Armstrong VII court determined that the National Security Council is not subject to the record-keeping or production requirements of

13. 90 F.3d 553 (D.C. Cir. 1996) [hereinafter Armstrong VII]. This decision represented the newest installment in nearly seven years of litigation between the Executive Office of the President (EOP) and several groups of historians and reporters.

While this dispute has numerous iterations (both published and unpublished) in the District Court and the Court of Appeals for the District of Columbia, this Note addresses issues contained in a relatively small number of them. Those cases are numerated and referred to infra. The entire controversy can be mapped as follows: Armstrong v. Bush, 721 F. Supp. 343, 364 (D.D.C. 1989) [hereinafter Armstrong I] (denying inotion to dismiss); Armstrong v. Bush, 924 F.2d 282, $289-91$ (D.C. Cir. 1991) [hereinafter Armstrong II] (holding that the Presidential Records Act (PRA) impliedly precludes judicial review of record-keeping decisions in connection with documents covered by the PRA); Armstrong v. Bush, 139 F.R.D. 547, 551-52, 554 (D.D.C. 1991) (limiting discovery of certain computerized records); Armstrong v. Bush, 807 F. Supp. 816, 820-23 (D.D.C. 1992) (issuing a temporary restraining order to prevent destruction of presidential materials pending decision on FOIA complaint); Armstrong v. Executive Office of the President, 810 F. Supp. 335, 340, 342-43 (D.D.C. 1993) [hereinafter Armstrong III] (holding that requested information was subject to the Federal Records Act (FRA) and that current record-keeping procedures were arbitrary and capricious); Armstrong v. Executive Office of the President, 821 F. Supp. 761, 768 (D.D.C. 1993) [hereinafter Armstrong $I V$ ] (finding the EOP and the NSC in contempt for failing to comply with earlier order); Armstrong v. Executive Office of the President, 823 F. Supp. 4, 8-9 (D.D.C. 1993) (denying motion for stay pending appeal); Armstrong v. Executive Office of the President, 829 F. Supp. 1, 2 (D.D.C. 1993) (staying motion for summary judgment on FOIA claims pending appeal); Armstrong v. Executive Office of the President, 1 F.3d 1274, 1296 (D.C. Cir. 1993) [hereinafter Armstrong V] (reversing conteinpt order but remanding to the district court to determine whether the NSC's guidelines were appropriate); Armstrong v. Executive Office of the President, 830 F. Supp. 19, 21-22 (D.D.C. 1993) (requiring production, under FOIA, of materials obtained by a former government official for part of his defense in a criminal trial concerning the testimony that he gave during the Iran-Contra investigation); Armstrong v. Executive Office of the President, 877 F. Supp. 690, 700-01, 704-06 (D.D.C. 1995) [hereinafter Armstrong VI] (liolding that the NSC is an agency subject to FOIA and must preserve its records in accordance with the FRA); Armstrong v. Executive Office of the President, 877 F. Supp. 750, 751-52 (D.D.C. 1995) (denying motion of stay pending appeal of order declaring the NSC to be an agency); Armstrong v. Executive Office of the President, 897 F. Supp. 10, 17-18 (D.D.C. 1995) (granting summary judgment to government for reprocessing of certain documents); Armstrong VII, 90 F.3d at 567 (reversing the district court's granting of summary judgment for Armstrong declaring that the NSC was an agency subject to FOIA and finding that the NSC is not an agency for FOIA purposes); Armstrong v. Executive Office of the President, 97 F.3d 575, 578-81 (D.C. Cir. 1996) (allowing certain exemptions to FOIA requests), cert. denied, 117 S. Ct. 1842 (1997). 
FOIA. ${ }^{14}$ As a practical matter, this decision foreclosed any citizen access to documents generated by the NSC within a reasonable period of time after their creation; indeed, given the lax recordspreservation standard that the court imposed, many potentially significant documents nay never see the light of public exposure.

Armstrong VII concerned several statutes that involve the dispersal of information held by the federal government, and it is important to distinguish these liere. First, FOIA grants broad public access to documents produced by the government, with certain statutory exemptions for various types of sensitive information. ${ }^{15}$ FOIA requires federal agencies ${ }^{16}$ to comply with rigorous standards of records production; ${ }^{17}$ these agencies must make nonexempt FOIA documents available to the public immediately after their creation. ${ }^{18}$ The President is not subject to FOIA, ${ }^{19}$ and nei-

14. See Armstrong VII, $90 \mathrm{~F} .3 \mathrm{~d}$ at 567. The court also held that the NSC was not subject to the FRA. See id. For a fuller description of the FRA, see infra notes 21-24, 52-55 and accompanying text.

15. See 5 U.S.C. $\$$ 552(b) (1994). Documents need not be disclosed if exempted because they are:

1) classified as relating to national defense or foreign policy;

2) related only to an internal personnel matter of an agency;

3) exempted specifically from disclosure by another act of Congress;

4) trade secrets, commercial, or financial information obtained from a privileged or confidential source;

5) inter-agency or intra-agency memoranda not normally available to the public;

6) personnel or medical files;

7) certain information relating to law enforcement;

8) related to the regulation or supervision of financial institutions; and

9) geological and geophysical information concerning wells.

See id. In the parlance of administrative law, the exemptions are generally referred to by number. See, e.g., infra note 198 and accompanying text.

16. For a discussion of what constitutes an agency under FOIA, see infra note 98 and accompanying text. Several previous decisions of the D.C. Circuit have discussed requirements for being deemed an agency for FOIA purposes. See, eg., Pacific Legal Found. v. Council on Envtl. Quality, 636 F.2d 1259, 1263 (D.C. Cir. 1980) (designating the Council on Enviroumental Quality as a FOIA "agency"); Sierra Club v. Andrus, 581 F.2d 895, 901-02 (D.C. Cir. 1978) (determining that the Office of Management and Budget is a FOIA "agency"); Soucie v. David, 448 F.2d 1067, 1075 (D.C. Cir. 1971) (holding that the Office of Science and Technology qualifies as an "agency" subject to FOIA).

17. See 5 U.S.C. \& 552(a) (1994).

18. See id. (discussing the procedures that an agency must follow when required to make information publicly available).

19. See Kissinger v. Reporters Comm. for Freedom of the Press, 445 U.S. 136, 156 (1980) (holding that the Office of the President is not included within FOIA's definition of "agency"); $c f$. H.R. REP. No. 93-876, at 8 (1974), reprinted in 1974 U.S.C.C.A.N. 6267, 6274 (stating that, while the EOP is subject to FOIA, the President himself is not); see also Franklin v. Massachusetts, 505 U.S. 788, 800-01 (1992) (finding that the President is 
ther are those arms of the Executive Branch that are indistinguishable from the President. ${ }^{20}$

While FOIA relates to the production of information, two other acts concern the maintenance of records by the government. The Federal Records Act (FRA) ${ }^{21}$ is intertwined with FOIA in that documents covered by the FRA are subject to immediate disclosure under FOIA. ${ }^{22}$ In order to dispose of a Federal Record, an agency must initially secure the approval of the Archivist $^{23}$ who will not approve of disposal if the record has "sufficient administrative, legal, research, or other value to warrant [its] continued preservation." 24 The Presidential Records Act (PRA) ${ }_{,}^{25}$ in contrast to the FRA, gives ultimate control to the President, rather than the Archivist, over documents created during the President's term of office. ${ }^{26}$ Departments of the Executive Branch which are indistinguishable from the President because of the types of duties which they undertake are subject to the PRA, and not the FRA. ${ }^{27}$ When the President leaves office, the Archivist is required to release Presidential Records "as rapidly and completely as possible;" however, the Archivist also has the option to dispose of those Presidential Records which she determines "have insufficient administrative, historical, informational, or evidentiary value." 28 Furthermore, the President is allowed to specify a length of time "not to exceed twelve years" for which access

not an agency under the Administrative Procedure Act).

20. See infra note 95 and accompanying text.

21. 44 U.S.C. $\$ \S 2101-2118,2301-2305,2501-2506,2701-2706,2901-2909,3101-3107$ (1994).

22. See Armstrong VI, 877 F. Supp. 690, 698 (D.D.C. 1995); supra note 18 and accompanying text.

23. See Armstrong VI, 877 F. Supp. at 698 (citing 44 U.S.C. $\S 3303 a$ (1994)). The Archivist is the individual in charge of the National Archives.

24. 44 U.S.C. $\$ 3303 \mathrm{a}$ (discussing the Archivist's ability to examine and facilitate disposal of records lacking preservation value).

25. Id. $\S \S 2201-2207$.

26. See Armstrong VI, 877 F. Supp. at 698. Before disposing of any presidential records, the President must "obtain the [non-binding] views" of the Archivist, 44 U.S.C. § 2203(c)(1) (1994), but, in the creation phase, the President decides which documents will be termed presidential records. See id. He is guided only by the PRA's directive that a President must "assure that the activities, deliberations, decisions, and policies that reflect the performance of his . . duties are adequately documented and ... maintained." Id. Furthermore, the President's "recordkeeping practices and decisions" are not subject to judicial review. Armstrong II, 924 F.2d 282, 291 (D.C. Cir. 1991).

27. See infra note 95 and accompanying text.

28. 44 U.S.C. $\$ 2203$. 
to Presidential Records concerning confidential advice between the President and his advisors will be restricted. ${ }^{29}$

Against the backdrop of these information access laws, the Armstrong VII decision is significant because it represents a further tightening of the judiciary's interpretation of FOIA, resulting in greater barriers for public access to government information. In recent years, exemptions to FOIA lave been construed quite broadly in order to limit the amount and variety of information released to the public. ${ }^{30}$ Unlike most litigation under FOIA, however, the Armstrong VII case did not arise through an agency's claim that requested inaterial falls within a statutory exemption and thus need not be released. ${ }^{31}$ Instead, it arose in response to the Executive Brancli's decision to sequester NSC records from FOIA by rescinding the NSC's status as a FOIA agency. This Note argues that the decision in Armstrong VII signals an even more restrictive standard than the Supreme Court's recent constructions of FOIA exemptions: without even determining that information slould not be released because it falls within a statutory exemption, the Executive Brancli may now strip an agency of FOIA duties simply by declaring that the agency is no longer an agency subject to the statute. ${ }^{32}$ In all likelihood, this decision will substantially shape FOIA law into the foreseeable future.

Part I of this Note reviews the factual background that developed over the course of a decade leading up to the decision in Armstrong VII. Part II dissects the D.C. Circuit's opinion in

29. Id. § 2204. The twelve-year period also govems the release of presidential records containing personnel and medical files. See id.

30. See, e.g., United States Dep't of Defense v. Federal Labor Relations Auth., 510 U.S. 487, 502 (1994) (finding that the privacy interest of nonunion employees in not revealing their home addresses to unions "substantially outweighs the negligible FOIArelated public interest in disclosure"); Department of Justice v. Reporters Comm. for the Freedom of the Press, 489 U.S. 749, 780 (1989) (holding that disclosure of a proininent businessperson's "rap sheet" was exempt under FOIA). But see WILliam F. FUNK, ET AL., ADMINISTRATTVE Procedure AND PRACTICE 590 (1997) (asserting that the exemptions have traditionally been construed "relatively strictly"); Christopher P. Beall, The Exaltation of Privacy Doctrines over Public Information Law, 45 DUKE L.J. 1249, 1257-58 (1996) (arguing that the recent restrictiveness imposed on FOIA information was not within the original contenplation of Congress).

31. FOIA, by its terms, suggests broadly that citizens have access to the "records" of any federal "agency." See 5 U.S.C. \& S52(a)(3) (1994). However, the exemptions to this standard often protect nore documents than they expose. See id. § 552(b) (listing a nultitude of documents which are not available to the public).

32. See infra note 96 and acconpanying text. 
Armstrong VII in an attempt to determine whether the NSC should be an agency subject to FOIA. Finally, Part III turns to the larger question that has pervaded FOIA hitigation recently: to what degree inay the Executive Branch restrain public access to information about the government?

\section{SETTING THE SCENE: THE NSC AND THE IRAN-CONTRA AFFAIR}

The inost important case in FOIA law in 1996, Armstrong $v$. Executive Office of the President (Armstrong VII), ${ }^{33}$ had its genesis in the cloistered chambers of the National Security Council over ten years ago. On November 25, 1986, the American public reeled in shock as President Ronald Reagan revealed on national television that up to $\$ 30$ million received from covert sales of U.S. arms by Israel to Iran had been diverted by American agents to rebels fighting against the Sandinista government of Nicaragua. ${ }^{34}$ Members of the National Security Council, who were close advisors to President Reagan, had circumvented exphicit declarations of Congress ${ }^{35}$ by structuring a series of clandestine transactions that filtered the profits from the arms sales to the Nicaraguan guerrillas (Contras). ${ }^{36}$ These members of the NSC determined that, although the tide of an intense partisan debate ${ }^{37}$ had turned against the Reagan administration's position on the Contras, resulting in Congress's moratorium on assistance, the Executive Branch would still play a role in shaping the internal policy of other nations. ${ }^{38}$

33. 90 F.3d 553 (D.C. Cir. 1996).

34. See David Hoffman, Iran Arms Profits Were Diverted to Contras; Poindexter Resigns, NSC Aide North is Fired, WASH. POST, Nov. 26, 1986, at A1.

35. In a series of statutes that became known collectively as the Boland Amendments, named for Rep. Edward P. Boland, Congress, beginning in 1982, banned military aid to the Nicaraguan rebels. See, e.g., Continuing Appropriations Act for Fiscal Year 1985, Pub. L. No. 98-473, $\$ 8066$ (a), 98 Stat. 1837, 1935 (1984).

36. See Hoffman, supra note 34 , at A1; see also infra note 38 (chronicling the debates over the issue of funding for the Contras).

37. See Joseph C. Harsch, The Third Term, Christian SCI. MonIroR, Mar. 24, 1987, at 15 (describing dichotomy between "what Mr. Reagan wants most, funds for weapons and contras, and what the Congress wants most-progress toward a balanced budget").

38. See, e.g., John Kohan, Aiming to Gain Ground: Talk of Peace, As the Fighting Goes On and On, TMME, Oct. 10,1983, at 28 (suggesting that a Contra offensive against the Sandinista regime was designed to persuade Congress to renew CIA funding for the rebels); Ed Magnuson, A Mystery Involving "Mercs": Deaths in Nicaragua Raise Questions 
Devising a plan that was by turns dazzling in its simplicity and horrifying in its ramifications, NSC staff member Lieutenant Colonel Oliver North served as the go-between, ferrying weapons to Iran and steering their proceeds to the Contras. ${ }^{39}$ In the drama that ensued for nearly a year following this initial revelation, Colonel North, National Security Advisor Vice-Admiral John Poindexter, Secretary of Defense Caspar Weinberger, and other aides of President Reagan were summoned before Congress, their schedules and motivations examined, and their links to the President scrutinized intently. ${ }^{40}$

In his initial announcement, President Reagan repeatedly denied any knowledge of the sclieme, stating early on that "I was not fully informed" about "one of the activities undertaken" after the 'secret weapons shipment to Iran. ${ }^{41}$ The day after the IranContra link was revealed, Reagan pronised the American people that "future foreign and national security policy initiatives will

About U.S. Involvement, TME, Sept. 17, 1984, at 33 (observing that American civilians continued to provide aid to the Contras even after Congress ended official funding); Anne Manuel, Nicaragua: U.S. Congress Strikes Heavy Blow at "Secret War," INTER PRESS SERVICE, Oct. 10, 1984 (recounting expressions of optimism by the Reagan administration and Republican Congressional leaders that Congress would once again fund the Contras in February 1985); Joanne Omang \& Don Oberdorfer, Ultimate Goal of U.S. Latin Policy Still Unresolved: "Military Shield" Changing Face of Region, WASH. POST, Apr. 29, 1984, at A1 (referencing the CIA legal department's ruling that Congress had the last word on Contra funding); Michael S. Serrill, Shot Out of the Sky: A Captured U.S. Soldier of Fortune Spins a Tale of CIA Intrigue, TIME, Oct. 20, 1986, at 44 (revealing that the Reagan administration maintained relationships with private organizations that covertly supplied the Contras after Congress had cut off official aid); Bob Woodward, CIA Sought 3rd-Country Contra Aid, WASH. POST, May 19, 1984, at A1 (reporting that the Contras continued to be funded even after Congress had refused to approve another grant to the rebels in April 1984).

39. See Chronology: Iran/Contra Crisis, in AMERICA AND THE WORLD 653 (Sara Robertson ed., 1986) (Council on Foreign Relations, Foreign Affairs Publication).

40. During the summer of 1987, Congress held joint hearings on the Iran-Contra affair at whicls a variety of individuals, including several high-ranking Executive Branch officials, testified on the matter. See generally Iran-Contra Investigation: Joint Hearings Before the Senate Select Committee on Secret Military Assistance to Iran and the Nicaraguan Opposition and the House Select Committee to Investigate Covert Arms Transactions with Iran, 100tli Cong. (1987).

41. Hoffman, supra note 34, at A1. Attorney General Edwin Meese also insisted that the President "knew nothing" about the illicit payments to the Contras, stating that North was the only person who "knew precisely" of the transactions and that Poindexter "did know that something of this nature was occurring, but he did not look into it further." Id. Later in the same day, Meese widened his net to include as co-conspirators "others who may have been working in some capacity" with North, but he never sug. gested that Reagan was one of those individuals. Id. 
proceed only in accordance with my authorization." ${ }^{42}$ This statement implies that, at least for a time, NSC policy was shaped not by Reagan, but by officials within the agency who never reported their deeds to him.

In perhaps the most frequently satirized part of the entire affair Fawn Hall, secretary to Colonel North, revealed that North liad instructed her to shred thousands of documents which might have further incriminated him and to sinuggle countless others from the Old Executive Office Building inside her clothing. ${ }^{43}$ In addition to incriminating North, most commentators believe these documents might have slown connections between the President and the deals, although the destruction of the documents rendered these beliefs largely speculative. ${ }^{44}$ Among the information reportedly destroyed were logs of telephone calls to North, coded messages from North's network of operatives, and electronic interoffice memoranda. ${ }^{45}$ The individuals investigated for their parts im the Iran-Contra affair always claimed that they acted alone, without the knowledge or consent of the President; these elusive docuinents might have shown otherwise. ${ }^{46}$

While the seeds of this scandal never blossoined into a catastrophe on the scale of Watergate, they certainly shook the federal government at its highest levels. ${ }^{47}$ For many Americans, the im-

42. Id. (emphasis added). Despite the President's and Vice President's protestations that they were never informed about the Contra aid, former Secretary of State Henry A. Kissinger said at the time that "I cannot imagine a lieutenant colonel or even an admiral like Poindexter doing this without somebody knowing." Id.

43. See Walter Pincus \& Dan Morgan, Hall Tells of Altering Data, Shredding Papers for North, WASH. Post, June 9, 1987, A1.

44. See id.

45. See id.

46. Hall, in her riveting testimony before Congress, did describe a North memorandum, believed to have been written in April 1986, which described how funds from the arm sales could be used to benefit the Contras. See id. This meinoranduin was forwarded to John M. Poindexter, who revised it and recommended that it be sent to the President. See id. Hall could not verify if the memorandun had been delivered to Reagan, but observed that "it was typed for a reason and that it went somewhere." Id.

47. Although the affair caused the towers of government to wobble, none ever fell. Former National Security Adviser Robert C. McFarlane, implicated in the cover-up, later attempted suicide, see David Hoffman, McFarlane Struggled to Cope with Career Dip, Friends Say; Police End Probe of Suicide Attempt, WASH. Post, Feb. 11, 1987, at A1, but none of the Iran-Contra actors was ever punished as a result of the hearings in the spring and summer of 1987. See, e.g., United States v. Poindexter, 951 F.2d 369, 371 (D.C. Cir. 1991) (reversing, in an opinion by Judge Ginsburg, Poindexter's conviction on the grounds that his compelled testimony before Congress was used against him at his 
age of the compliant Hall forcing answers to important questions into a paper shredder lingered on long after the hearings had ended but eventually receded into memory. For one group of historians, however, the search for answers continued. That quest took a disappointing turn during the summer of 1996.

\section{A. The Dispute over the NSC's Iran-Contra Documents}

On January 19, 1989, the last day of the Reagan presidency, a reporter, Scott Armstrong, and the National Security Archive ${ }^{48}$ submitted several FOIA requests for copies of all the information stored on the Executive Office of the President (EOP) and NSC electronic communications systems from their installation in the mid-1980s until that time. ${ }^{49}$ Tapes from these systems contained not only copies of soine of the records which North and Hall later destroyed, ${ }^{50}$ but also encoded computer inessages which might have included additional information about the arms diversion scheme. ${ }^{51}$ At the same time, the National Security Archive filed suit in the United States District Court for the District of Columbia seeking a declaratory judgment against the EOP, the Office of Administration, the National Security Council, the White House Communications Agency, and the Archivist of the United States that the documents contained on the electronic communications

trial in violation of 18 U.S.C. $\$ 6002$ and the Fifth Amendment); United States v. North, 910 F.2d 843, 852 (D.C. Cir. 1990) (reversing, per curiam, North's conviction on the grounds, inter alia, that the District Court failed to hold a full hearing to ensure that the independent counsel did not use North's immunized testimony against him at his trial).

48. The National Security Archive is a private non-profit organization which pursues disclosure of imformation relating to defense and national security policy. See Eileen V. Quigley, Washington's Movers and Shakers: at the Bar, NAT'L J., Mar. 1, 1986, at 523 (noting that the National Security Archive is designed as "a source of declassified and unclassified documents for use by academics and journalists").

49. See Armstrong I, 721 F. Supp. 343, 347 (D.D.C. 1989). Since their installation, the electronic communications systems have allowed the sharing of electronic appointment calendars, the electronic transfer of word processing documents, and the exchange of electromic mail (e-mail). See Armstrong V, 1 F.3d 1274, 1279 (D.C. Cir. 1993). The 1300 federal employees in the EOP who use e-mail often relay "lengthy substantive-even classified-'notes' that, in content, are often indistinguishable from letters or memoranda." Id. Perhaps most important is the fact that e-mail creates a "log" of entries of letters sent and received, see $i d$, and that the government periodically creates backup tapes which preserve everything on the system at a given moment in time. See id. at 1280.

50. See Dubious Distinctions, COMPUTERWORLD, INC., Dec. 28, 1987, at 14. The tapes are components of the central computer archive, IBM's Professional Office System. See id.

51. See Armstrong V, 1 F.3d at 1280 (D.C. Cir. 1993). 
systems and their backups were Federal Records subject to the Federal Records Act ${ }^{52}$ and an injunction prohibiting their destruction. 53

The significance in labelling these documents Federal or Presidential Records is profound, because Federal Records are subject to FOIA, while Presidential Records are not. ${ }^{54}$ Although certaim safeguards exist to prevent wanton destruction of Presidential Records, the fact remains that Presidential Records can be destroyed.5 In addition, before the conclusion of his term of office, the President specifies a duration, "not to exceed 12 years, for which access shall be restricted with respect to [national defense] information, in a Presidential Record." allows the restriction of virtually all information that might be found in Presidential Records, most significantly records involving

52. See supra notes $21-24$ and accompanying text. The Federal Records Act is designed to insure "[a]ccurate and complete documentation of the policies and transactions of the Federal Government," 44 U.S.C. $\$ 2902(1)$ (1994), "[c]ontrol of the quantity and quality of records produced by the Federal Government," id. $\S 2902(2)$, and "judicious preservation and disposal of records." Id. § 2902(5); see also Armstrong II, 924 F.2d 282, 292 (D.C. Cir. 1991) (observing that the FRA is designed to insure that agencies' records management programs "strike a balance 'between developing efficient and effective records management, and the substantive need for Federal records."') (quoting S. REP. No. 94-1326, at 2 (1976)).

53. See Armstrong $V, 1 \mathrm{~F} .3 \mathrm{~d}$ at 1280 . "If a document qualifies as a federal record, the FRA prohibits an agency from discarding it by fiat." Id. at 1278; see also American Friends Serv. Comm. v. Webster, 720 F.2d 29, 62 (D.C. Cir. 1983) ("Congress did not intend to grant the [agency] ... a blank check for records disposal.").

54. See supra text accompanying notes 21-29.

55. See Armstrong $V, 1$ F.3d at $1290-91$. Just as FOIA requires strict adherence to a record-production convention, the FRA sets out demanding guidelines in the realm of records preservation; in that sense, the FRA ultinately protects more documents than the PRA. See id.; accord Armstrong VII, 90 F.3d 553, 556 (D.C. Cir 1996). Also, the recordkeeping requirements of the FRA are subject to judicial review, while those of the PRA are not. See Armstrong $V, 1$ F.3d at 1290-91. Furthermore, the PRA is applicable to a President's papers only after he has left office, while the FRA can affect the President while he is in office. See id. Finally, documents subject to the FRA may not be removed by the President upon leaving office without the approval of the Archivist. See id.; see also 44 U.S.C. $\S 3106$ (1994) (providing that the Attorney General may initiate legal action to retrieve records unlawfully removed by the President). The PRA, which both parties agree applies to most NSC documents, makes those documents publicly available "as rapidly and completely as possible" after the President leaves office. 44 U.S.C. $\S$ 2203(f)(1) (emphasis added). But see 44 U.S.C. \& 2204 (restricting access to presidential records after the conclusion of the President's term for certain categories of information). Significantly, the PRA "does not include any documentary materials that are . . official records of an agency." 44 U.S.C. § 2201(2)(B); see also supra notes $25-29$ and accompanying text.

56. 44 U.S.C. \& 2204(a). 
confidential communications between the President and his advisors. $^{57}$

After extensive litigation whether the records qualified as protected docunients under the statutory standards of the FRA, the District Court affirmatively settled the question on January 6, 1993, nearly four years after the initial requests and suit liad been filed. ${ }^{58}$ The court held that, because the FRA's definition of "records" includes material "regardless of physical form or characteristics,"59 the communications at issue (the saved e-mail) did constitute Federal Records. ${ }^{60}$ Armstrong and the National Security Archive then sought full production of the e-mail, including the encrypted computer messages contained on it, but the government agencies balked; they argued that they had "reasonably discharged [their] FRA obligations" by maintaining paper versions ("hard copies") of the electronic communications. ${ }^{61}$ The court disagreed, and it ordered the NSC and EOP to make its electronic records management guidelines comport with the $\mathrm{FRA}^{62}$ and to review periodically its employees' electronic record-keeping practices. ${ }^{63}$

The EOP did not comply with the court's order. Four months later, on May 21, 1993, the plaintiffs petitioned the District Court to require the EOP to show cause why it should not be held in contempt of the court's order to produce the docunients and to

57. See Armstrong VI, 877 F. Supp. 690, 707 (D.D.C. 1995).

58. See Armstrong III, 810 F. Supp. 335, 335 (D.D.C. 1993).

59. 44 U.S.C. $\$ 3101$.

60. See Armstrong III, $810 \mathrm{~F}$. Supp. at 340-41. The court's holding did not include "non-record or presidential record materials" that were not the subject of the plaintiffs suit. Id. at 340 .

61. Armstrong V, 1 F.3d 1274, 1277 (D.C. Cir. 1993).

62. See Armstrong III, $810 \mathrm{~F}$. Supp. at 342.

63. See id. at 343. The District Court found that the EOP practices for electronic records management were deficient in two respects. First, the court observed that even if the EOP employees printed out all on-screen information that qualified as a federal record, a process which the government claimed was already in place, the record would be incomplete absent the attachment of the transmittal information stored in the computer network but not appearing on the screen, such as the names of all individuals receiving the information. See id. at 341 (concluding that "[a] paper copy of the electronic material does not contain all of the information included in the electronic version"). An example of this information is the copies of the electronic data preserved after North's and Hall's destruction of the hard copies. See Dubious Distinctions, supra note 50, at 14. Second, the court found that the records management practices utilized by the EOP's agencies failed to provide for any supervision of agency employees' electronic record-keeping practices, a failure which the District Court found to be arbitrary and capricious. See Armstrong III, $810 \mathrm{~F}$. Supp. at 343. 
create safer record-keeping practices. ${ }^{64}$ The plaintiffs referred to the EOP's having issued interim guidance instructions which failed to preserve all records in accordance with the court's January 6 order. ${ }^{65}$ The court found the EOP in contempt and also held that the conditions surrounding the transfer of certain Iran-Contra period backup tapes from the White House to the National Archives on January 19, 1993 (President Bush's last day in office), violated the court's orders requiring preservation of the tapes. ${ }^{66}$

On appeal, the D.C. Circuit held that, because the District Court's original orders did not specify that the government had an affirmative duty to create new guidelines by a particular date, the lower court should not have held the government in contempt for its failure to promulgate new guidelines within four months, given the government's "speeded-up attempts in recent months to assure preservation of the tapes. ${ }^{\circ 67}$ Nonetheless the court affirmed that the NSC and EOP guidelines violated the FRA, and remanded the case to the district court to determine whether any requested documents classified as Presidential Records should be released under FOIA. ${ }^{68}$

\section{B. The FOIA Component of the Litigation}

Only after the court had determined how to classify the documents did the hitigation turn to the FOIA requests. The D.C. Circuit's opinion in Armstrong $V$ opened the door for the NSC to turn over the requested information. ${ }^{69}$ Shortly thereafter, the Clinton administration's Office of Legal Counsel (OLC) responded by issumg a memorandum, written by Walter Dellinger (Dellinger Memorandum), stating that the NSC was not an agency for FOIA purposes. ${ }^{70}$ This surprising move represented a reversal of a Sept-

64. See Armstrong IV, 821 F. Supp. 761, 763 (D.D.C. 1993).

65. See id. at 766-68.

66. See id. at 768-71. For example, some of the backup tapes were in poor condition; the guardians of the tapes failed to recopy those in advanced states of deterioration, thereby increasing the likelihood of destruction. See id. at 770 .

67. Armstrong $V, 1$ F.3d 1274, 1277 (D.C. Cir. 1993).

68. See id. at 1296 .

69. See id. at 1277. The opinion was issued on August 13, 1993. See id.

70. See Armstrong VII, 90 F.3d 553, 557 (D.C. Cir. 1996) (citing Memorandun from Walter Dellinger, Acting Assistant Attorney General, Office of Legal Counsel, to Alan J. Kreczko, Special Assistant to the President and Legal Advisor, National Security Council (Sept. 20, 1993)) [hereinafter Dellinger Memorandum]. The proclamation also signified that the NSC was not subject to the provisions of the FRA. See id. In the interest of 
ember 6, 1978 Memorandum by the OLC, which stated that the NSC was an agency for FOIA purposes. ${ }^{71}$ In its 1978 statement, the OLC addressed the concerns of those who felt that FOIA might unconstitutionally intrude upon the President or the NSC: "[D]ue to the nature of the work of the NSC and its staff it is clear that valid exemptions are available for the vast bulk of the material which constitutes NSC records." ${ }^{.72}$ As to the question whether coinplete immunity froin FOIA could ever be achieved by the NSC, the 1978 OLC thought it most clearly could not: "Nor could it be shown on evidence now available that the act's impact on NSC is so onerous that its ability to function in support of the President will be impaired." ${ }^{.73}$ Despite this clear language in the earlier stateinent, the Dellinger Memorandum did not seek to offer any explanation why the situation of the NSC had changed.

President Clinton subsequently approved the OLC's revised stance but indicated that the NSC should "voluntarily" make some records available. ${ }^{74}$ On March 24, 1994, two significant events occurred. First, the National Archives and Records Administration $^{75}$ promulgated new regulations applicable to all Federal agencies. ${ }^{76}$ Second, President Clinton, in a memorandum to National Security Advisor Anthony Lake and NSC Executive Secretary William Itoh, directed that the NSC "[e]stablisln procedures

full disclosure, it is significant to note that Professor Dellinger sits on the faculty of Duke University School of Law and on the Board of the Duke Law Journal.

71. The 1978 Meniorandum was issued in conjunction with President Carter's signing the Presidential Records Act into law. See Armstrong VII, 90 F.3d at 576 (Tatel, J., dissenting) (citing 2 Op. Off. Legal Counsel 197, 205 (1978)).

72. Id. at 579 (Tatel, J., dissenting) (quoting 2 Op. Off. Legal Counsel 197, 205 n.15).

73. Id.

74. Id. at 557 (quoting Memorandum from the President (Mar. 2, 1994)). These records would include those that had been "transferred by one Administration to another for transition and continuity purposes." Id. (quoting Memorandum from the President (Mar. 2, 1994)).

75. This agency is responsible for promulgating procedures concerning the storage and maintenance of governmental records. See 44 U.S.C. $\$ \S 2108-2110$ (1994) (prescribing the duties of the Archivist of the United States, who heads the National Archives and Records Administration).

76. See Notice of Proposed Rulemaking, 59 Fed. Reg. 13,906, 13,906 (1994). In addition, certain components of the Executive Office (notably, the Office of Administration, the Office of the United States Trade Representative, the Office of Management and Budget, the Office of National Drug Control Policy, and the Council of Environmental Quality) received further guidehines on July 15, 1994. See Armstrong VI, 877 F. Supp. 690,695 n.3, 715-40 (D.D.C. 1995). 
for access by the public to appropriate NSC records of the current Administration." "77 Based on Clinton's language, it appeared that lie was autliorizing the NSC to comply with FOIA requests; lowever, the next day, Secretary Itoh issued a written memorandum echomg the OLC's position that the NSC is not an "agency" and that all of its records are therefore Presidential Records subject to the PRA, ${ }^{78}$ and thus are outside the ambit of FOIA. ${ }^{79}$

The problem with this scenario, aptly illustrated by the background to this case, is twofold. First, documents created by the NSC or by the President $\dot{m}$ association with the NSC, would, under the administration's position, be labeled Presidential Records, and thus become destroyable or at least suppressible for up to twelve years after the conclusion of a President's term. ${ }^{80}$ The documents created and destroyed by Colonel North and his associates demonstrate the problem with this arrangement. ${ }^{81}$

Furthermore, unscrupulous members of an administration might shift functions from a recognized "agency" to the NSC-or simply create certam documents under the auspices of the NSC. Even though these documents might technically become available later under the PRA, the NSC will not be required to establish exacting policies for the storage and retrieval of documents that the FRA and FOIA require. ${ }^{82}$ For example, the electronic mail cache files at issue in Armstrong VII would not be protected under the PRA; they could be deleted permanently at any time, by any NSC employee. Consequently, the government could potentially use the NSC as a repository for documents to which it does not wish the public to have access.

In addition, the announcement that the NSC was no longer an agency obviated nearly twenty years of the NSC's referring to itself as such and producing documents pursuant to FOIA as a result of that moniker, ${ }^{83}$ the D.C. Circuit's endorsement of this

77. Id. at 696 (quoting Memorandum from the President to Anthony Lake, National Security Advisor, and William H. Itoh, National Security Council Executive Secretary (March 24, 1994)).

78. See id. For a brief explanation of the PRA, see supra notes $25-29,55-56$ and accompanying text.

79. See Armstrong VII, 90 F.3d at 559.

80. See supra notes $55-57$ and accompanying text.

81. See supra notes $43-46$ and accompanying text.

82. See 5 U.S.C. \& 552(a) (1994).

83. See Armstrong VI, 877 F. Supp. at 696 n.5. The fact that the NSC was, at least until March 25, 1994, subject to FOIA is not even contested by the government. See id. 
approach $^{84}$ sets a troublesome precedent. Apparently, the NSC decided that it would be less burdensome simply to take itself out of FOIA altogether than to store its documents under the rigorous requirements of FOIA and the FRA; as the late Judge Charles Richey of the District Court opined, this move was "contrary to law [and] without any reasoned explanation." 85

Recognizing these potential pitfalls, the District Court found chilling the prospect that an arm of the government could unilaterally remove a department of government from the sphere of public access. ${ }^{86}$ Accordingly, on February 14, 1995, the D.C. District Court granted Armstrong's motion for summary judgment, holding that the NSC was indeed an agency. ${ }^{87}$

Needless to say, the government was not satisfied with the overruling of its position that the NSC was not an agency, and it appealed to the D.C. Circuit again. In the course of its appeal, the government urged that the President's dealings with the NSC require privacy and confidentiality and should be shielded from FOIA. ${ }^{88}$ The Government asserted that, despite the exemption for national security information, the mere possibility of "premature disclosure" of information would chill the President's commumications with the NSC and adversely affect his development of

at 706. On October 7, 1994, the government filed a Motion to Withdraw and Amend Prior Responses to Requests for Admissions with the District Court for the District of Columbia, wherein the NSC had characterized itself as an "agency" subject to FOIA and to the FRA. See id. at 697 n.8.

84. See Armstrong VII, 90 F.3d at 565-66 (holding that the NSC is no longer an agency subject to FOIA despite its former status as such).

85. Armstrong VI, 877 F. Supp. at 697; cf. Greater Boston Television Corp. v. FCC, 444 F.2d 841,852 (D.C. Cir. 1970) (holding that a decision to reconstrue the nature of a governmental unit must be reasonable in order not to be held arbitrary and capricious).

86. The district court's decision in Armstrong VI reflects concems similar to those voiced by Judge Patricia Wald in her dissent in Meyer v. Bush:

[The majority's approach] clearly maps out the formula for getting around disclosure laws in the [EOP]: First, put a small unit of decisionmakers atop a larger estabhishment of persons who carry out those decisions, and insist that because only the implementers have a staff, only they form the "agency." Second, when necessary, maintain that the "significant authority" resides only with the implementers and that the "whole" of the decisionmaking unit is less than the sum of its parts. That is, if you sever the "brains" of an organization from the "body," the people who call the shots are never in the public's sights.

981 F.2d 1288, 1315 (D.C. Cir. 1993) (Wald, J., dissenting) (citations omitted).

87. See Armstrong VI, 877 F. Supp. at 697.

88. See Armstrong $V I I, 90$ F.3d at 557 . 
foreign policy. ${ }^{89}$ The stage was thus set for 1996's most significant FOIA decision.

\section{FOIA COVERAGE of EXECUTIVE BRANCH AgENCIES}

\section{A. The NSC and Agency Status}

Prior to the D.C. Circuit's decision im Armstrong VII, it was unquestioned that the NSC exercised substantial imdependent authority, and was in fact an agency which made its records accessible under FOIA..$^{90}$ And, altliough the D.C. Circuit lias never expressly established that the NSC is an agency under FOIA, ${ }^{91}$ it lias spoken often on the issue of agency status for other entities within the EOP. ${ }^{22}$ In previous decisions, the D.C. Circuit, using a rationale adopted in Soucie v. David ${ }^{93}$ has lield that certain units of the EOP are agencies subject to the requirements of FOIA, usually enploying the rationale that they operated less as an arm of the President and inore like independent agencies. ${ }^{94}$ Those eleinents of the EOP whicli do not constitute FOIA agencies tend to

89. Id.

90. See Armstrong VI, 877 F. Supp. at 706.

91. The D.C. Circuit and other courts which have addressed FOIA in conjunction with the NSC have always characterized the NSC as an agency, or, more precisely, sinply assumed that it is one. See, e.g., Kissinger v. Reporters Comm. for Freedom of the Press, 445 U.S. 136, 156 (1980) (discussing the NSC as an agency under FOIA); National Sec. Archive v. Archivist of the United States, 909 F.2d 541, 542 (D.C. Cir. 1990) (observing, without further comment, that FOIA requests were filed with the NSC); Rush v. Department of State, 748 F. Supp. 1548, 1549 (S.D. Fla. 1990) (noting that the NSC reviewed documents for FOIA release); Willens v. National Sec. Council, 726 F. Supp. 325, 325,327 (D.D.C. 1989) (describing FOIA transaction between plaintiff and the NSC). In an unpublished opinion, Mangold v. CIA, No. 88-1826, 1989 U.S. Dist. LEXIS 18421, at *5 (D.D.C. May 3, 1989), the court mentions that the NSC announced to a FOIA requester that the request was delayed because of a backlog of FOIA requests which it was processing.

92. See, e.g., Pacific Legal Found. v. Council on Envtl. Quality, 636 F.2d 1259, 1262-63 (D.C. Cir. 1980) (designating the Council on Environmental Quality as a FOIA agency because of its authority as an independent entity to "issue guidelines to federal agencies," "coordinate federal programs," and oversee discrete activities of other agencies); Sierra Club v. Andrus, 581 F.2d 895, 902 (D.C. Cir. 1978) (determining that the Office of Management and Budget is a FOIA agency due to its statutory duty to provide budgetary information to Congress); Soucie v. David, 448 F.2d 1067, 1075 (D.C. Cir. 1971) (holding the Office of Science and Technology to be a FOIA agency because of its independent authority to evaluate federal scientific programs, involve itself in research, and award scholarships).

93. 448 F.2d at 1073-75.

94. See Armstrong VII, 90 F.3d at 558-59; see also supra note 92 (collecting cases). 
be those which have no regulatory functions suggesting independent authority. ${ }^{95}$

Reinarkably, the Armstrong VII court held that the NSC was no longer an agency. ${ }^{96}$ In the course of its opinion, the court emphasized that units of the EOP whose sole functions are to advise and assist the president are not "agencies." In other words, units which do not exercise "substantial independent authority" are not agencies. ${ }^{98}$

In adopting this position, the court applied the test that it first articulated in Meyer v. Bush. ${ }^{99}$ That opinion attempted to elucidate the status of entities within the EOP by suggesting that an entity which "help[s] the President supervise others in the

95. See, e.g., Sweetland v. Walters, 60 F.3d 852, 854-55 (D.C. Cir. 1995) (holding that the Staff of the Executive Residence is not covered under FOIA because those individuals manage the White House subject to the President's direction and approval, and without significant independent authority); Rushforth v. Council of Economic Advisors, 762 F.2d 1038, 1043 (D.C. Cir. 1985) (finding that the Council of Economic Advisors is not subject to FOIA because it lacks the regulatory powers that an agency exercising independent authority would normally possess).

96. See Armstrong VII, 90 F.3d at 559.

97. See id. at 563 .

98. Id. at 555-62; see also supra note 16. As a preliminary matter, FOIA defines an "agency" as "any executive department, military- department, Government corporation, Government controlled corporation, or other estabhishment in the executive branch of the Government (including the Executive Office of the President), or any independent regulatory agency." 5 U.S.C. § 552(f) (1994). This definition is substantially more specific than that included elsewhere in the Administrative Procedure Act: "each authority of the Government of the United States, whether or not it is within or subject to review by another agency." 5 U.S.C. \& 551(1) (1994). As discussion of Armstrong VII will denionstrate, the federal courts have greatly restricted this broad definition of "agency" in recent years. See generally infra text accompanying notes 123-89. In particular, the D.C. Circuit has limited access to documents produced by certain EOP units under a strict test first annunciated in Meyer v. Bush, 981 F.2d 1288, 1291 (D.C. Cir. 1993). See infra text accompanying notes 101-02. This distinction-between the plain language of FOIA and the court's interpretation of that language-originated with Congress' effort, in its 1974 amendments to FOIA, to codify that portion of the D.C. Circuit's Soucie opinion, see 448 F.2d at 1073, 1074, which included the Executive Office of the President among the list of "agencies" generally subject to FOIA. See S. CONF. No. 93-1200, at 15 (1974), reprinted in 1974 U.S.C.C.A.N. 6285, 6293 (stating that "[w]ith respect to the meaning of the term 'Executive Office of the President' the conferees intend the result reached in Soucie v. David"). In 1980, the Supreme Court held, based on the 1974 legislative history, that FOIA did not apply to "the President's immediate personal staff or units in the Executive Office whose sole function is to advise and assist the President." Kissinger v. Reporters Comm. for Freedom of the Press, 445 U.S. 136, 156 (1980) (quoting H.R. CoNF. REP. No. 93-1380, at 15 (1974)). The Kissinger Court found that only the National Security Advisor himself was excluded from FOIA coverage; it did not extend its holding to the entire NSC. See FUNK ET AL., supra note 30, at 595.

99. 981 F.2d 1288 (D.C. Cir. 1993). 
executive branch" only exercises substantial independent authority in certam situations. ${ }^{100}$ Apart from mere advice and assistance to the President, under the Meyer test an "agency" exists when 1) the unit is not in close proximity to the President, 2) the "nature of [the unit's] delegation from the President," is such that it has the potential to exercise independent authority ${ }^{101}$ and 3) the unit

100. Id. at 1295 .

101. "Independent authority" may take one of two forms within the agency framework of the federal government. It is firmly established that Congress, with the approval of the President, may delegate power to administrative "agencies." Administrative agencies include both executive agencies (Cabinet Departments, e.g., Commerce, and their subunits, e.g., the International Trade Administration) and imdependent regulatory agencies (outside any Department, e.g., the Federal Trade Cominission). See FUNK ET AL., supra note 30, at 11-12. Indeed, only two such delegations have ever been declared unconstitutional. See A.L.A. Schechter Poultry Corp. v. U.S., 295 U.S. 495, 541-42 (1935) (declaring the National Industrial Recovery Act's (NIRA) "fair competition" provisions invalid because they supplied the President with "virtually unfettered" control over trade and industry); Panama Refining Co. v. Ryan, 293 U.S. 388, 432-33 (1935) (holding unconstitutional an NIRA provision which delegated power to the President without providing an intelligible principle for its exercise).

The delegation of power to independent agencies led to debates about their constitutionality in the early part of the century, largely because the Constitution vests the entire power of government in three coordinate branches-Legislative, Executive, and Judicial-and not in amalgamated structures which exercise each of these responsibilities within a single organization. See FUNK ET AL., supra note 30, at 469. During the New Deal, the myriad agencies created by the Roosevelt administration to combat the Great Depression presented the federal judiciary with the novel question whether these independent agencies could be countenanced under the Constitution. To a great degree, this question turned on the ability of the agencies to perform the functions of government outside the reach of the Executive and Legislative branches. In the seminal case of Humphrey's Executor v. United States, 295 U.S. 602 (1935), a unanimous Supreme Court greatly abetted the rise of independent agencies as a permanent part of government by holding that, while the President could remove from office individuals who were "merely one of the units in the executive departinent," id. at 627 (for example, the Secretary of Cominerce), the President had no power over those individuals who maintain "no place in the executive department and who exercise[] no part of the executive power." Id. at 628 (for example, in Humphrey's, the Chair of the FTC); compare Myers v. United States, 272 U.S. 52, 134 (1926) (holding that the President may exercise "unrestricted power" in directing the actions to be taken by his executive subordinates) with THE FEDERALIST No. 70 (Alexander Hamilton) (rejecting the notion of a "plural executive" in favor of a centralized system which vests power exclusively in a unitary authority) and EdWARd S. CORWIN, THE President: OfFicE AND Powers, 1787-1984 3-30 (Randall W. Bland et al. eds., 5th ed. 1984) (same). By implication, the newly created independent agencies were not exclusively the "executive departments," but shared elements of executive, legislative, and judicial authority. See Gerhard Casper, An Essay in Separation of Powers: Some Early Versions and Practices, 30 WM. \& MARY L. REV. 211, 238-42 (1989); Nathan D. Grundstein, Presidential Power, Administration and Administrative Law, 18 GEO. WASH. L. REV. 285, 298-302 (1950). The distinguishing feature of independent agencies, then, is that they are created by Congress but possess functions typical of each 
has "a self-contained structure." Executive Branch meets the three parts of the Meyer test, it is an agency for FOIA purposes.

In its application of the Meyer test to the facts of Armstrong, lowever, the court turned in a different direction, allowing one prong of the test to subsume the other two. Although the record in the case demonstrated that "responsibilities delegated to the NSC are im fact carried out without the personal involvement of the President,"103 in applying the first prong, the court found that the NSC is proximate to the President mostly because he is himself a member of it. ${ }^{104}$ Of course, the President is an ex officio member of other EOP groups, ${ }^{105}$ and, as Judge David Tatel observed in his dissent, independent functions are often exercised by the less-proximate NSC staff and by numerous NSC interagency groups in which the President does not directly participate. ${ }^{106}$

branch, with the exception that the President may not exercise removal power over agency officials. See Wiener v. United States, 357 U.S. 349, 356 (1958) (holding that the adjudicatory nature of the War Claims Commission implicitly limited the President's power to remove); Humphrey's Executor, 295 U.S. at 631-32 (restricting the ability of the President to remove non-Executive Branch officials). But see Buckley v. Valeo, 424 U.S. 1, 143 (1976) (holding that the Federal Election Commission, an independent agency, was unconstitutional as constituted because it violated the Appointments Clause of Article II by circumventing the appointment procedure for "Officers of the United States").

It almost goes without saying, then, that presidential control and supervision over the decisions of independent agency officers is limited. See Cass R. Sunstein, Constitutionalism after the New Deal, 101 HARV. L. REV. 421, 444 (1987). But see id. at 454 (noting that the Reagan administration attempted to control the independent agencies by concentrating regulatory authority in the Office of Managenent and Budget). While the final word on the extent of the President's control over independent agencies is still disputed, see id. at 452-62, it seems clear that, if the President has the constitutional power to delegate authority to an independent agency, he certainly may delegate to an agency entirely within the Executive Branch (such as the NSC).

102. Meyer, 981 F.2d at 1293.

103. Armstrong VII, 90 F.3d at 569 (Tatel, J., dissenting).

104. See id. at 560. The majority found the fact that the President heads the NSC "overwhelming" in its determination that the "the NSC is not an agency subject to FOIA." Id. at 565. By making this seemingly insignificant logical leap (from the President's being on the Council to its serving solely to advise and assist the President), the court created a heavy burden for Armstrong to surmount regarding the nature of the authority delegated to the NSC. Meyer, however, stipulated that Congress intended the phrase "solely to advise and assist" the President to symbolize entities which were similar to the President's immediate personal staff. Meyer, 981 F.2d at 1293. The phrase should have nothing to do with whether the President is a member of the agency.

105. For example, the President is a member of the Council on Environmental Quality and the Office of Science and Technology, both of which are FOIA agencies. See Meyer, 981 F.2d at 1291-92.

106. See Armstrong VII, 90 F.3d at 568 (Tatel, J., dissenting). 
Skipping to the third prong, the meinbers of the court did not dispute that the NSC has a self-contained structure. ${ }^{107}$ Plainly, the NSC is structured such that it may exercise substantial independent authority. ${ }^{108}$

The court instead concentrated on the second prong of the test, the nature of the authority delegated to the NSC. In its most basic form, the NSC is an entity created by Congress with several significant responsibilities that Congress authorized it to undertake. ${ }^{109}$ The President has also delegated power to the NSC. ${ }^{110}$ Notwithstanding the delegations of power made to the NSC, the court found that the nature of that power was not sufficiently independent; rather, the NSC has reinained always an instrument intended to advise and assist the President. ${ }^{111}$ Thus, because the

107. See id. at 559-60, 568 (Tatel, J., dissenting). The district court also characterized the NSC as having a "firm structure," including staff and a separate budget. See Armstrong VI, 877 F. Supp. 690, 700-01 (D.D.C. 1995).

108. See Armstrong VII, $90 \mathrm{~F} .3 \mathrm{~d}$ at 560 . The NSC has a hierarchical organization chart, an elaborate self-contained bureaucracy, and a "professional corps" of over 150 people, all enblematic of an agency as defined by the Meyer test. Id.

109. See National Security Act of 1947, 50 U.S.C. $\S 402$ (a)-(b) (1994). The NSC is authorized to: (a) advise the President upon national security matters; (b) coordinate the policies and functions of other departments and agencies regarding national security matters; (c) assess and appraise the objectives and commitments of, and the risks facing, the United States; (d) consider policies on national security matters; and (e) make recommendations to the President. See id. Armstrong argued persuasively that the Act conveys certain non-advisory authority on the NSC. For example, the Director of Central Intelligence acts "[u]nder the direction of the National Security Council," 50 U.S.C. \& 403-3(a)(1), and "as the President or the National Security Council may direct," id. § 403-3(c)(6). Nevertheless, the majority in Armstrong VII determined that the NSC does not "direct" the CIA absent an order from the President. See Armstrong VII, 90 F.3d at 561.

110. Cf. Armstrong VII, $90 \mathrm{~F} .3 \mathrm{~d}$ at 570 (Tatel, J., dissenting) (contrasting those units within the EOP which merely assist the President with those to which the President has delegated responsibility for action). But cf. id. at 561 (holding that the NSC does not have enough presidential delegation of power to act independently). The district court determined that successive presidents, through Executive Orders and National Security Decision Directives, have expanded the NSC's involvement beyond its statutory mandate: the NSC performs rulemaking and adjudicatory functions, and plays an independent role in intelligence, telecommunications, protection of national security information, arms control verification, nonproliferation, and public diplontacy. See Armstrong VI, 877 F. Supp. at $701-03$.

111. See Armstrong VII, 90 F.3d at 561. The court submits as proof of this fact a statement from the report of the Tower Commission: the NSC "has from its inception been a highly personal instrument of the President' and 'remain[s] a strictly advisory body." Id. (quoting JOHN TOWER ET AL., REPORT OF THE PRESIDENT'S SPECIAL REVIEW BOARD at II-1, II-2 (1987)). The Tower Commission was created by President Reagan to investigate the involventent of NSC staff members in the Iran-Contra affair. 
court found that the NSC's power was not sufficiently independent, the court held that the NSC is not an agency for the purposes of FOIA. ${ }^{112}$.

\section{B. Critique of the Court's Holding}

The Armstrong VII holding can be criticized on many grounds. In order to evaluate the court's conclusion about the NSC's authority, it is significant first to consider that the NSC bears an unusual relationship to the President and to the Executive structure. On the one hand, the NSC, as a unit of the EOP, is part of the immediate cadre of advisors and officials whose locus is strictly within the Executive Branch of the federal governnent. As such, it is dissimilar from independent agencies, which have a more attenuated relationship to the Executive Branch. ${ }^{113}$ Additionally, most departments within the Executive Branch are "agencies" for the purpose of FOIA. ${ }^{114}$ These agencies have

See Exec. Order No. 12,575, 3 C.F.R. § 241 (1987).

112. See Armstrong VII, 90 F.3d at 565.

113. See supra note 101. Independent agencies are functionally neither within the Executive Branch nor truly outside it. They are "independent of political forces generally" and reside in a "headless fourth branch" which is subject to the President's influence, but not his or Congress's direct control. Michael Herz, United States v. United States: When Can the Government Sue Itself?, 32 WM. \& MARY L. REV. 893, 948-49 (1991). The characterization of independent agencies as "headless" was originally conceived in derogation by the Brownlow Commission in the 1930's, when the agencies' continued existence was still in doubt. See THE President's COMM'N ON ADMN. MANAGEMENT, REPORT OF THE COMMTTEE WITH STUDIES OF ADMINISTRATTVE MANAGEMENT IN THE FEDERAL GOVERNMENT (1937), reprinted in SUBCOMM. ON SEPARATION OF POWERS, COMM. ON THE JUdicIARY, U.S. SENATE, SEPARATION OF POWERS AND THE INDEPENDENT AGENCIES: CASES AND SELECTED READNGS, S. DOC. No. 91-49, at 34 (1969). While independent agencies were roundly criticized during their inception in the Franklin Roosevelt administration, "the rubric of the headless fourth branch has persisted, acting as a useful rhetorical pejorative despite prevailing judicial and scholarly opinion that it is a 'constitutional impossibility." Morton Rosenberg, Congress's Prerogative Over Agencles and Agency Decisionmakers: The Rise and Demise of the Reagan Administration's Theory of the Unitary Executive, 57 GEO. WASH. L. REv. 627, 635 (1989) (citation omitted). Ultimately, the Supreme Court upheld the constitutionality of independent agencies, and has continued to do so despite repeated challenges. See, e.g., Morrison v. Olson, 487 U.S. 654, 659-60 (1988) (holding that a statutory scheme designed to protect administrative officials from Executive control is constitutional); Humphrey's Executor v. United States, 295 U.S. 602, 625-26 (1935) (holding that the NLRB was "independent of executive authority" and "free to exercise its judgment without the leave or hindrance of any other official or any department of the government"). But of. Bowsher v. Synar, 478 U.S. 714, 732-34 (1986) (holding that an official who may be removed from office by Congress may not possess executive powers).

114. See supra note 92. FOIA refers to "establishment[s] in the executive branch" as 
been created both by acts of Congress (as the NSC was) and by Executive fiat. ${ }^{115}$

The NSC has as its principal function "to advise the President with respect to the integration of domestic, foreign, and military policies relating to the national security" and to perform "such other functions as the President may direct." "116 However, the President inay (and often does) delegate additional responsibilities to Executive Office agencies such as the NSC. ${ }^{117}$ When the President makes such a delegation, the characterization of an agency's role within the EOP changes dramatically: an entity performing a delegated function is no longer primcipally "advismg" the President. Rather, it is undertaking a duty which, in the absence of the agency, another Executive Branch unit or even the President himself, would be required to perform. Assisting the President in this fashion is quite attenuated from the type of aid contemplated by the "advise and assist" exception to FOIA; if sucl were not the case, then every Executive Branch agency, from the EOP units to the Environmental Protection Agency, would no longer be subject to FOIA since each one in some way "assists" the President with his duties. In his impassioned dissent, Judge David Tatel warned that, by construing the "advise and assist" language in broad terms, the court was laying the groundwork for excepting all EOP

agencies. See 5 U.S.C. $\$ 552(f)$ (1994). For additional discussion of the term "agency," see supra notes 101,113, and accompanying text.

115. See Meyer v. Bush, 981 F.2d 1288, 1303 (D.C. Cir. 1993) (Wald, J., dissenting) (observing that the authority granted to an agency may originate with Congress or with the President).

116. National Security Act of 1947,50 U.S.C. $\S 402(a)-(b)$ (1994). The Council consists of the President and several cabinet-level officials, imcluding the National Security Adviser (NSA)-technically called the Assistant to the President for National Security Affairs. See Armstrong VII, 90 F.3d at 556. The NSC's staff consists of approximately 150 people, see id., and is headed by an Executive Secretary, appointed by the President without Senate approval, who reports to the NSA. See 50 U.S.C. § 402(c) (1994).

117. See infra notes 159-73 and accompanying text. In this sense, the President's delegation authority is no different from that of Congress vis-à-vis the President himself. Congress often makes spending powers discretionary on the part of the Executive Branch; by so doing, the Legislative Branch is delegating its power to spend under Article I of the Constitution to the President, who has no such independent authority under Article II. See Raines v. Byrd, 117 S. Ct. 2312 (1997) (discussing the line-item veto while clearly contemplating that such a delegation may be constitutional). This practice has persisted since the founding of the Republic, with judicial approbation, yet one would never suggest that the President is "assisting" Congress in any substantial fashion. The only "assistance" which the President provides is cursory and flows from Congress's decision to voluntarily cede some of its authority to another branch of government. 
units from FOIA merely because the President's imvolvement could somehow be traced to the various units. ${ }^{118} \mathrm{He}$ wrote that "the 'advise and assist' exception [has] swallow[ed] the FOIA rule,"119 for any delegation the President makes can, if read broadly enough, be interpreted to be for the purpose of assisting him. ${ }^{120}$

By way of example, consider the case of the Staff of the Executive Residence (Staff) versus the NSC. In Sweetland $v$. Walters, ${ }^{121}$ the court correctly held that the Staff did not constitute an agency because its members only offered advice and assistance to the President. ${ }^{122}$ This distinction with the NSC should be immediately apparent: the Staff assists the President by maintaining the physical plant of the White House, duties clearly not delegated to it by the President but rather performed as the sole function of the Staff's existence. By contrast, the NSC not only advises and assists the President under its statutory mandate; it also performs duties expressly delegated to it by the President and removed from his immediate oversight. The same can and has been said of, inter alia, the Office of Management and Budget, the EPA, and the various subentities of the Cabinet departments.

Although the Armstrong VII court held that these delegated duties did not amount to imdependent functions, ${ }^{123}$ history plainly demonstrates that the NSC does more than simply "advise and assist"124 the President, notwithstanding the language of its statutory mandate; it forms and implements its own agendas. For example, during and after the Iran-Contra affair, President Reagan successfully propounded his claim that he was never aware of the actions taken by his subordinates in the NSC. ${ }^{125}$ Taken at face value, this suggests that the NSC does nore than serve in an advisory capacity.

The campaign donations scandal that recently occupied Congress is also mstructive on this point. In the days surrounding

118. See Armstrong VII, 90 F.3d at 569.

119. Id.

120. See id.

121. 60 F.3d 852 (D.C. Cir. 1995).

122. Id. at 854-55.

123. See Armstrong VII, 90 F.3d at 561, 565; supra notes $110-12$ and accompanying text.

124. For an early examination of this concept, see Soucie v. David, 448 F.2d 1067, 1075 (D.D.C. 1971).

125. See supra notes $41-42$ and accompanying text. 
the 1996 election and in the inonths following, potential indiscretions in Deinocratic Party fundraising came to liglit. ${ }^{126}$ In particular, the press centered on President Clinton's numerous invitations to wealthy Democratic Party supporters to visit the White House as well as his meetings with a controversial Chinese-American businessman, Johnny Chung. ${ }^{127}$ The Washington Post discovered that the NSC had written a memorandum to President Clinton describing Chung as a "hustler" and suggesting that the President not entertain hinn. ${ }^{128}$ Clinton denied ever seeing the inemorandum, stating "I never saw it and no one ever told ne it had been written, and I don't know who did see it."129 The Washington Post summed up the problein with this rhetorical question, which might have been written for this Note with a slight alteration: "Why did the National Security Council memo describing Chung as a hustler and warning about too much contact with him never reach the Oval Office [if the NSC's sole function is to advise and assist the President, and it never acts absent his explicit knowledge or consent]?"130 Notwithstanding this incident or the Iran-Contra niachinations in which the NSC played a central role, and in which President Reagan urged that the NSC undertook actions without his explicit approval or request, the administration con-

126. See, e.g., Charles R. Babcock, Indonesian Businessman Riady Met with Clinton to Discuss Business, WASH. POST, Nov. 5, 1996, at A4 (describing a September 1995 meeting between President Clinton and Indonesian businessman and major Democratic donor, James Riady, at which the latter raised his concerns about personal business projects); John F. Harris, Indonesian Provided Hospitality for DNC Chairman's Daughter, WASH. PosT, Nov. 3, 1996, at A31 (reporting favor provided to DNC Chairman Donald Fowler by the Lippo Group, an Indonesian financial conglomerate headed by the Riady family).

127. See, e.g., Andrew Miga, Clinton: Might Have Made White House Fund Calls, BosTON HERALD, Mar. 8, 1997, at 1 (recounting allegations of illegal and improper fundraising at the White House and one of President Clinton's visits with Johnny Chung, a controversial businessman and Democratic donor, who is alleged to have bought access to the President and other key figures in the Clinton administration for foreign businessmen).

128. See Sharon LaFraniere \& Susan Schmidt, NSC Gave Warnings about Asian Donors, WASH. POST, Feb. 15, 1997, at A1. The NSC had alerted the President that Chung was "a hustler" who would attempt "to trade on his connections to President Clinton and Hillary Rodham Clinton, even presenting himself as a free-lance diplomat for the president." Id. Notwithstanding this warning, White House aides admitted Clung to the Executive Mansion numerous times. See id.

129. Transcript of President Clinton's News Conference, WASH. POST, Mar, 8, 1997, at A10.

130. Dan Balz, Lawyerly Stance Delivered with Campaign Style, WASH. POST, Mar. 8, 1997, at A1. 
tends, and the D.C. Circuit holds, that the NSC is not an "agency" because it never exercises independent authority or undertakes independent action.

Another strong criticism of the Armstrong VII decision is that precedent supports the conclusion that the NSC is an agency. ${ }^{131}$ The NSC itself has, for most of the life of FOIA, considered itself to be an agency. ${ }^{132}$ The NSC complied with FOIA as early as 1975, when it issued FOIA regulations. ${ }^{133}$ In addition, other units of the government considered the NSC to be an agency for FOIA purposes. ${ }^{134}$ Further, the legislative history of the 1974 FOIA Amendments suggests that Congress also intended for the NSC to be treated as an agency for FOIA purposes. ${ }^{135}$ Congress explicitly stated that the amended FOIA definition of "agency" would encompass "such finctional entities as ... the National Security Council." "While the Court of Appeals for the D.C. Circuit previously refused to rely on this report since a subsequent Conference Report endorsed the Soucie test without enumerating specific FOIA agencies, ${ }^{137}$ the Supreme Court has cited the 1974

131. See Armstrong VII, 90 F.3d 553, $577-78$ (D.C. Cir. 1996) (Tatel, J., dissenting) (discussing prior cases which stand for the proposition that an agency should not be treated as a non-agency simply because it may perform advisory functions).

132. See id. at 576.

133. See Freedom of Information Act Requests for Classified Documents-Processing, Fees, Reports, Applicable Material, Declassification Criteria, Partial Release, 40 Fed. Reg. 7316, 7316 (1975) (codified at 32 C.F.R. $\$ 2101$ (1996)). Furthermore, in 1975, 1976, 1977, and 1978, the NSC complied with FOIA's requirement that "each covered agency annually submit a copy of its FOIA regulations and a report of its administration of FOIA to the Speaker of the House of Representatives and to the President of the Senate for referral to appropriate congressional committees." Armstrong VII, 90 F.3d at 576 (Tatel, J., dissenting); see also 5 U.S.C. \& 552(e) (1994) (setting out the FOIA requirement to report to the Speaker of the House and the President of the Senate).

134. See CONGRESSIONAL ReSEARCH SERVICE, LIBRARY of CONGRESS, APPLICABILITY OF THE FREEDOM OF INFORMATION ACT TO THE EXECUTIVE OFFICE OF THE PRESIDENT 20 (1978), reprinted in Presidential Records Act of 1978: Hearings Before a Subco. mm. of the House Comm. on Government Operations on H.R. 10998 and Related Bills, 95th Cong. 759, 778 (1978) [hereinafter PRA Hearings]. The Congressional Research Service concluded that eight units of the EOP, including the NSC, were agencies for FOIA purposes. See $i d$. The Report observed that "[t]he NSC has FOIA regulations and has been the subject of court cases under the Act. The NSC has an active FOIA component." Id. at 8, reprinted in PRA Hearings, supra, at 766. Furthermore, the Office of Legal Counsel advised President Carter that the NSC is an agency under FOIA. See 2 Op. Off. Legal Counsel 197, 205 (1978).

135. See H.R. REP. NO. 93-876, at 8 (1974), reprinted in 1974 U.S.C.C.A.N. 6267, 6274.

136. Id.

137. See Rushforth v. Council of Econ. Advisors, 762 F.2d 1038, 1040 (D.C. Cir. 
House report and referred to it as "indicating that the National Security Council is an executive agency to which ... FOIA apphes." 138

A further criticism of the Armstrong decision lies in its reliance on the theory that the NSC-as-agency has negative constitutional ramifications. The administration argued that if the NSC were allowed to remain an agency, such power would overlap with the nature of the President's power as enumerated under Article II of the Constitution. ${ }^{139}$ Although the government argues that subjecting the NSC to FOIA "would violate constitutional separation of powers principles by intruding improperly into the President's exercise of his constitutional duties," 140 the Supreme Court has suggested otherwise. ${ }^{141}$ While the government in this case anticipated unconstitutional intrusions if NSC documents were made available to the public, ${ }^{142}$ there is no evidence that such intrusions ever occurred during the time the NSC complied with FOIA under Presidents Ford, Carter, Reagan, and Bush, or in the first year of President Clinton's administration. ${ }^{143}$ Furthermore,

1985); see also supra notes 93-94 and accompanying text (describing the Soucie test).

138. Kissinger v. Reporters Comm. for Freedom of the Press, 445 U.S. 136, 156 (1980). The Court held that documents related to the activities of the Assistant to the President for National Security Affairs when "act[ing] in his capacity as a Presidential adviser, only" were not subject to FOIA. Id. (emphasis added). This statement implies that the NSA may act in other, non-advisory capacities.

139. Principally, the concern advanced by the government is that having to adhere to record-keeping procedures mandated by FOIA would interfere with the President's duty to "take Care that the Laws be faithfully executed." U.S. CONST. art. II, \& 3.

140. Armstrong VII, 90 F.3d 553, 578 (D.C. Cir. 1996) (Tatel, J., dissenting).

141. See Nixon v. Administrator of Gen. Servs., 433 U.S. 425, 445 (1977) (holding that "abundant statutory precedent [exists] for the regulation and mandatory disclosure of documents in the possession of the Executive Branch"). The Supreme Court, in applying FOIA to forner President Nixon's presidential papers and tape recordings, indicated that FOIA, as applied to material "generated in the Executive Branch," is not "considered invalid as an invasion of [the Executive Branch's] autonomy." Id.

142. See Armstrong VII, 90 F.3d at 555.

143. See Armstrong VII, 90 F.3d at 578 (Tatel, J., dissenting). Since no problems of a constitutional nature have yet arisen, it is appropriate to apply the maxim adopted by the Supreme Court not to "'anticipate a question of constitutional law in advance of the necessity of deciding it."' Ashwander v. Tennessee Valley Auth., 297 U.S. 288, 346 (1936) (Brandeis, J., concurring) (quoting Liverpool, New York \& Philadelphia S.S. Co. v. Emigration Comm'rs, 113 U.S. 33, 39 (1885)). If a particular constitutional separation of powers issue confronts the President in his ability to carry out his duties, then the D.C. Circuit may reconsider its decision to hold certain aspects of the NSC subject to FOIA. See Armstrong VII, 90 F.3d at 579 (Tatel, J., dissenting) (quoting Nixon, 433 U.S. at 443, for the proposition that "the proper inquiry focuses on the extent to which [an act of Congress] prevents the Executive Branch from accomplishing its constitutionally assigned 
since FOIA already exempts materials classified "in the interest of national defense or foreign policy,"144 if FOIA were applied to the NSC, the documents recoverable under the statute would clearly not pose a substantial risk "of improper intrusion into the President's exercise of his constitutional responsibilities."145 Indeed, the President could have FOIA-proof interactions with his National Security Advisor by explicitly requesting that individual's advice and/or assistance. ${ }^{146}$ Perliaps most important is that the government offers no persuasive rationale that distinguishes the NSC's sensitive role from that of other agencies, sucli as the Departunent of State or the Central Intelligence Agency, which are subject to FOIA and which engage in "sensitive foreign affairs." ${ }^{147}$ Ironically, none of these problenus materialized in the twenty years that the NSC, as an "agency," complied with FOIA.

Another criticisn of the opimion is the availability of the "dual-hat" rationale to make certain NSC documents available to the public. The Suprenie Court, in Kissinger v. Reporters Committee for Freedom of the Press, ${ }^{148}$ endorsed the rationale that an individual serving a department of government may wear niore than one "hat."149 When an individual serves in two capacities, as an advisor to the President and as a meniber of an agency, that

functions. Only where the potential for disruption is present must we then determine whether that impact is justified by an overriding need to promote objectives within the constitutional authority of Congress.").

144. 5 U.S.C. \& 552(b)(1)(A) (1994).

145. Armstrong VII, 90 F.3d at 579 (Tatel, J., dissenting). In 1978, the Office of Legal Counsel of the Department of Justice concluded that, if the NSC were subject to FOIA, this status would not place an unconstitutional burden on the President or the NSC:

[D]ue to the nature of the work of the NSC and its staff it is clear that valid exemptions are available for the vast bulk of the material which constitutes NSC records. ... We have also considered whether NSC could raise a valid constitutional claim to general immunity from the FOIA, and we believe this possibility is very weak. Certain records of the NSC could, if necessary, be protected by a claim of executive privilege, but such a claim could not successfully be invoked to preclude Congress from opening to public view some NSC administrative records and other nonsensitive records to which the claim could not reasonably attach. Nor could it be shown on evidence now available that the Act's impact on NSC is so onerous that its ability to function in support of the President will be impaired.

Id. (Tatel, J. dissenting) (quoting 2 Op. Off. Legal Counsel 197, 205 n.15 (1978)).

146. See Armstrong VII, 90 F.3d at 579.

147. Id. at 580 (Tatel, J., dissenting).

148. 445 U.S. 136 (1985).

149. See id. at 156 (holding that notes made by the National Security Advisor qua Presidential advisor were not agency records despite his dual role as an official of the NSC, where his notes were records of the agency). 
person's records are not subject to FOIA in the prior instance, but are in the latter. ${ }^{150}$ For example, the D.C. Circuit held that cabinet members could be subject to FOIA as heads of agencies, but not as members of the Task Force on Regulatory Relief. ${ }^{151}$ The Meyer dissent also observed that the records of the Vice President "in his capacity as advisor to the President" were distinct from those "that were received or generated by the Task Force which he chairs."'152 But the court in Armstrong VII pointedly avoids this "dual-hat" discussion, an issue that, if considered, would have altered the outcome of the case. ${ }^{153}$ Indeed, as Judge Tatel rightly observed in his dissent, "nothing in FOIA ... supports treating agencies or their parts as non-agencies whenever they perform advisory functions;",154 rather, only those advisory documents are exeinpted from FOIA. When a member of an agency performs a non-advisory function, her documents have traditionally been imcluded as FOIA documents. ${ }^{155}$

The Armstrong VII decision can also be attacked on the ground that the court found that the principal purpose of the NSC is to advise and assist the President and that the agency is therefore not "independent" of the President. ${ }^{156}$ Judge Tatel observed

150. See, e.g., id. (holdimg that documents produced as a result of Kissinger's interaction with the President were not subject to FOIA); $c f$. Ryan v. Department of Justice, 617 F.2d 781, 786-89 (D.C. Cir. 1980) (finding that the Attomey General would not be an "agency" under FOIA when she acts solely in an advisory capacity to the President).

151. See Meyer v. Bush, 981 F.2d 1288, 1297 (D.C. Cir. 1993).

152. Id. at 1311 n.21 (Wald, J., dissenting).

153. See Armstrong VII, 90 F.3d at 558.

154. Id. at 577 (Tatel, J., dissenting). Judge Tatel's dissent merely carries forward the D.C. Circuit's prior resolution of this point in Ryan. See Ryan, 617 F.2d at 787-89. Because all EOP units are subject to FOIA except those whose sole functions are to advise and assist the President, see Armstrong V, 1 F.3d 1274, 1295 (D.C. Cir. 1993), and since some entities subject to FOIA also advise and assist the President, it follows that certain individuals might sometimes be exempt from FOIA, while the agencies thenselves will not be exempt under the "not-an-agency" rationale. See Armstrong VII, 90 F.3d at 577-78 (Tatel, J., dissenting). In a situation in which the individual moves from her agency position to her advise-and-assist position, those latter records are not agency records. See id. at 578. At all times, however, the agency itself remains subject to FOIA. See id. (delineating the distinction by observing that "otherwise qualifying records in the control of NSC officials while acting in NSC capacities should be considered agency records for purposes of FOIA ... even if such officials [in some circumstances] ... act to advise or assist the President").

155. See supra notes $148-50$ and accompanying text.

156. Ironically, the 1978 Memorandum establishing that the NSC was subject to FOIA admits that the NSC functions "in support of the President." 2 Op. Off. Legal Counsel 197, 205 n.15; see supra note 73 and accompanying text. Even so, the Carter administra- 
that, if this reasoning were stretched, there would be no way for any 'EOP unit ... [to] be 'independent' of the President in the way that independent agencies outside the executive branch can." 157 In other words, according to the majority at least, since the NSC cannot act over the objection of the President, it therefore is not imdependent; this tautology is quickly exposed since the NSC, like other semi-independent entities, does in fact act without the President's specific approval in many situations. Saying that the President's failure to object to an action is tantamount to active approval is laughable hyperbole. The President has not, nor, would one assunie, does he want to be mvolved in the quotidian aspects of the NSC's functioning. ${ }^{158}$ In fact, the NSC carries out several functions which do not directly involve giving advice or assistance to the President. ${ }^{159}$ Any one of these functions should suffice to indicate that the NSC is an agency for purposes of FOIA, because, despite the fact that in some instances NSC activities will be exempt from FOIA, the NSC's many independent functions still define it as an agency. Two such functions will serve as instructive examples.

First, in the area of pubhic diplomacy, the NSC's interagency groups have substantial independent authority. ${ }^{160}$ The NSC Special Planning Group is responsible for overseeing "public diplomacy activities" and must ensure that "a wide-ranging program of effective mitiatives is developed and implemented to support national security pohicy, objectives and decisions."161 For example, the Special Planning Group supervises a variety of subgroups, mcluding the International Political Committee, whose objective is

tion did not view those duties as limiting the FOIA coverage of NSC documents. See id.

157. Armstrong VII, $90 \mathrm{~F} .3 \mathrm{~d}$ at 572 (Tatel, J., dissenting).

158. The government argued in the alternative that, because the NSC shares some of its authority with other agencies, and it has never had to implement other elements of its authority, it is not subject to FOIA. See Armstrong VII, 90 F.3d at 563. According to Meyer, however, the "sole function" test concerns the question whether the EOP unit is or is not too similar to the President's personal staff; if it is not too similar (meaning that it takes some action that is independent of the President), then it is an agency. See Meyer, 981 F.2d at 1293. Furthermore, just because the NSC cooperates and shares duties with another agency does not exempt it from FOIA; it simply means that both agencies are "potentially subject to FOIA." Armstrong VII, 90 F.3d at 572-73 (Tatel, J., dissenting).

159. See Armstrong VII, $90 \mathrm{~F} .3 \mathrm{~d}$ at 568-69 (Tatel, J., dissenting).

160. See id. at 574 (Tatel, J., dissenting).

161. Id. (Tatel, J., dissenting) (quoting National Security Decision Directive 77, at 1 (Jan. 14, 1983) [lereinafter NSDD 77]). 
to provide "aid, training and organizational support for foreign governments and private groups to encourage the growth of democratic pohtical institutions and practices." ${ }^{\text {162 }}$ This type of training clearly goes beyond "assisting the President."163

The International Broadcasting Committee, another committee concerned with public diplomacy and overseen by the Special Planning Group, undertakes technical planning relating to international broadcasts, ${ }^{164}$ activities that "are almost certainly independent of any direct involvement by the President." 165 If, as the majority beheved, such activity is not independent of the President because it conforms "to overall goals fixed by the President,"166 every activity of every executive branch actor would be exempt from FOIA, since every executive action in some way relates to a goal of the President. ${ }^{167}$ But it has been estabhished by the D.C. Circuit itself that other elements of the EOP are FOIA agencies. ${ }^{168}$ Here, as elsewhere in this discussion, "[t]he key question is not who sets the goals toward which an entity works, but whether an entity itself takes action in furtherance of executive branch goals."169 Because the Special Planning Group is charged with "the overall planning, direction, coordination and momitoring of implementation of pubhic diplomacy activities, ${ }^{, 170}$ it almost surely exercises "substantial independent autlority." 171

162. Id. at 574-75 (Tatel, J., dissenting) (quoting NSDD 77, supra note 158, at 2).

163. Id. at 575. (Tatel, J., dissenting). If this action could be considered "assisting the President," then "nearly all executive branch activity" would be subsumed under that heading. Id. (Tatel, J., dissenting).

164. See id. (Tatel, J., dissenting) (citing NSDD 77, supra note 158, at 3). These planning activities include the implementation of anti-jamming devices to ensure that broadcasts reach their intended targets. See id. (Tatel, J., dissenting).

165. Id. (Tatel, J., dissenting).

166. Id. (Tatel, J., dissenting) (quoting the majority opinion).

167. See id. (Tatel, J., dissenting).

168. See supra note 92 and accompanying text.

169. Armstrong VII, 90 F.3d at 575 (Tatel, J., dissenting).

170. Id. (Tatel, J., dissenting) (quoting NSDD 77, supra note 158, at 1).

171. Id. (Tatel, J., dissenting). Judge Tatel also believed that the Special Planning Group's function of "periodically review[ing] the activities of the four permanent coordinating committees to insure that plans are being implemented and that resource commitments are commensurate with established priorities," id. (Tatel, J., dissenting) (quoting NSDD 77, supra note 158, at 1), was similar to the Office of Science and Technology's (OST) independent authority to evaluate federal scientific programs, initiate and support research, and award scholarships that warranted agency treatment of the OST in an earlier D.C. Circuit opinion. See id. (Tatel, J., dissenting) (citing Soucie v. David, 448 F.2d 1067, 1075 (D.C. Cir. 1971)). 
Second, in the realm of emergency preparedness, the NSC exercises independent authority delegated to it by the President. The NSC sets the guidelines for contingent einergencies, and these guidelines inust be followed by other agencies. ${ }^{172}$ Interestingly, if it were true that the President and the NSC are inseparable insofar as policy and decisionmaking go, why would the President, in his executive orders, need to specify that other agencies should adhere to NSC proclamations? ${ }^{173}$ Other agencies would simply follow the NSC's direction as equivalent to the President's direction, and this stipulation would seem redundant, unless the NSC is a separate and easily cognizable entity. ${ }^{174}$

172. See Exec. Order No. 12,656 § 104(a), 3 C.F.R. 586 (1989), reprinted in 42 U.S.C. $\S 5195$ note (1994). However, in Armstrong VII, the government argued that, notwithstanding this delegation, the NSC functions only as the "principal forum" for policy consideration. See Armstrong VII, 90 F.3d at 563 (quoting Exec. Order No. 12,656 § 104(a)).

173. See Exec. Order No. 12,919 § 104(c), 3 C.F.R. 902 (1995), reprinted in 42 U.S.C. $\S 5195$ (1994) (requiring that the heads of all entities of the federal government with responsibility for national defense preparedness inust ensure adherence to NSC "policy and guidelines" in that area).

174. The NSC also exercises some independent authority in the areas of information security, nuclear nonproliferation, and telecommunications. See Armstrong VII, 90 F.3d at 570-74 (Tatel, J., dissenting). An example of such authority in the information security area is the NSC's discretion to determine "whether waivers should be granted to permit federal agencies to use non-standard security forms." Id. at 570 (Tatel, J., dissenting). The pertinent regulation states that, "as part of a 'government-wide information security program' to 'enhance the protection of national security information and/or [to] reduce the costs associated with its protection,' executive branch departments and independent agencies must use a standard non-disclosure form." Id. (Tatel, J., dissenting) (alteration in original) (quoting 32 C.F.R. $\$ 2003.1$ (1995)). Employees of these units must sign the form "before being granted access to classified information," id. (Tatel, J., dissenting) (quoting 32 C.F.R. \& 2003.20(b)-(c)); despite the fact that use of the standard form is "mandatory," id. (Tatel, J., dissenting) (quoting 32 C.F.R. § 2003.2), "an agency may request a waiver from ... using the standard form," id. (Tatel, J., dissenting) (citing 32 C.F.R. § $2003.20(\mathrm{k})$ ), and "“[o]nly the National Security Council may grant an agency's request for a waiver from the use of the [standard form]."' Id. (Tatel, J., dissenting) (alterations in original) (quoting 32 C.F.R. $\$ 2003.20(\mathrm{k})$ ). As part of this process, the NSC receives a report from the Director of the Information Security Oversight Office and the Department of Justice before it alone determines whether the waiver will be granted. See id. (Tatel, J., dissenting).

An example of the NSC's independent authority in the area of nuclear nonproliferation is its authority to "review and make recommendations regarding export license applications." Id. at 573. (Tatel, J., dissenting). The regulations implementing section 309 (c) of the Nuclear Non-Proliferation Act of 1978, 42 U.S.C. $\$ 2139$ a(c) (1994), are the starting place for such authority. Id. (Tatel, J., dissenting). That Act gave the Secretary of Commerce the duty "to initiate procedures for review of export licenses covering 'items ... that could be of significance for nuclear explosive purposes if used for activities other than those authorized at the time of export." Id. (Tatel, J., dissenting) (quoting 15 C.F.R. $\$ 778$ A.2(a) (1996)). If the Secretary, in consultation with the Department 
Another criticisin involves the fact that the line which the majority attempts to draw between agencies and non-agencies is an artificial one. It is with arbitrary fiat that the court considers the Office of Science and Teclnology's or the Council on Environmental Quality's regulatory duties to be more independent than those of the NSC. The President could just as easily inject his opinion, and, indeed, his orders, into the day-to-day functionimg of those entities as he could to that of the NSC. The difference for the court apparently lies in the type of information which it would like to exempt from even basic FOIA consideration.

That information is that which might reflect poorly on the United States' imtelligence or military operations im this country and abroad. Traditionally, FOIA requests to the FBI and the CIA, two entities which are indisputably agencies under FOIA or any other statute, have faced the greatest opposition to disclosure and, consequently, requests backlog for years in these agencies. ${ }^{175}$ While FOIA was eventually amended to address the FBI/CIA administrative problem and facilitate more timely replies, adjudication often centers on the question whether those agencies are moving fast enougli or im a non-arbitrary manner. ${ }^{176}$ This question was apparently put to rest by the D.C. Circuit's opinion two

of Energy, believes that an export license application should be denied or reviewed by another agency, the application must be referred to the Subgroup on Nuclear Export Coordination (SNEC) of the NSC Ad Hoc Group on Nonproliferation. Id. (Tatel, J., dissenting). The SNEC "shall [tlien] promptly consider any such application and provide its advice and recounmendations to the Department of Commerce."' Id. (Tatel, J., dissenting) (quoting Procedures Establislied Pursuant to the Nuclear Non-Proliferation Act of 1978, 15 C.F.R. § 778, supp. 1 (1996) [hereinafter Non-Proliferation Procedures]). "If the SNEC reaches agreement on the application, the Commerce Department must consider the SNEC's recommendation ... and must give the license applicant an opporturity to respond to a negative SNEC recommendation." Id. (Tatel, J., dissenting) (citing 50 U.S.C. App. $\S 2409(f)(1)(2)(1994)$ ). If the SNEC does not find accord as to its recommendation, then it "may refer the matter to the NSC Ad Hoc Group on Non-Proliferation . . . or afterward to the President." Id. (Tatel, J., dissenting) (emplasis added) (citing NonProliferation Procedures, 15 C.F.R. § 778, supp. 1 (1996).

175. See, e.g., Electronic Privacy Info. Ctr. v. FBI, 865 F. Supp. 1, 2 (D.D.C. 1994) (finding that the FBI's backlog of over eleven thousand pending requests did not excuse its failure to process a FOIA request in a timely manner).

176. Although an agency generally has ten working days to determine if it will comply with a FOIA request, it can get a ten working-day extension in "unusual circumstances," such as requests involving voluminous records or multiple agencies or offices. See 5 U.S.C. $\S 552(a)(6)(A)-(B)$ (1994). Additional time may be allowed only in "exceptional circumstances" and only if "the agency is exercising due diligence in responding to the request." Id. $\S 552(\mathrm{a})(6)(\mathrm{C})$. 
decades ago in Open America v. Watergate Special Prosecution Force, ${ }^{177}$ which gave the government soine leeway in producing documents requested under FOIA. ${ }^{178}$

However, despite the rubric established in Open America to identify which delayed responses to FOIA requests are justified, courts still frequently inust resolve questions surrounding the FBI's and CIA's backlog delay. ${ }^{179}$ On one level, the D.C. Circuit's decision in Armstrong VII is unabashedly self-interested. If the court can restrain curious information-seekers from delving into yet another sensitive area, it will conserve judicial resources and avoid having to address repeatedly the backlog issue. In this case, Armstrong sought information about the NSC froin a time at which it was most vulnerable: the Iran-Contra years of the mid-1980s. ${ }^{180}$ It is entirely possible that a motivation of the court is to keep the floodgates of information about this era dammed. Notwithstanding the possibility of such a rationale, the NSC overwhelmingly satisfies the court's own standard for agencies, and should be treated as such for purposes of FOIA.

Additionally, it is troublesome that the D.C. Circuit's decision forces individuals like Armstrong "to show that the NSC exercises significant independent authority in order to qualify it as an agency."181 Traditionally, the burden of proof lies with the plaintiff to show that a document held by an agency is a record pursuant to FOIA, ${ }^{182}$ but the administration's recharacterization of the NSC changes the playing field. Since the government has sole access to information which proves whether an entity is or is not an agency,

177. 547 F.2d 605 (D.C. Cir. 1976).

178. See id. at 615-16. In Open America, the court, in interpreting FOIA section 552(a)(6)(C), found "exceptional circumstances" present when the FBI was able to show the court that 1) it was backlogged "with a volume of requests for information vastly in excess of that anticipated by Congress;" 2) "existing resources [were] inadequate to deal with the volume of requests within the time limits of [5 U.S.C. $₹ 552(\mathrm{a})(6)(\mathrm{A})]$;" and 3) the agency was "exercising due diligence" in processing the requests. Id. at 616. As a result, the D.C. Circuit validated the F.B.I's first-in, first-out program for handling requests and construing the statutory time provision in such cases such as "directory" rather than mandatory. See id.

179. See Electronic Privacy, 865 F. Supp. at 2 (denying the FBI's motion to stay a FOIA request for release of surveys of state and local law enforcement authorities in connection with FBI director Louis J. Freeh's efforts to secure a new wiretapping law).

180. See supra notes $33-47$ and accompanying text.

181. Armstrong VII, 90 F.3d 553, 559 (D.C. Cir. 1996).

182. See id. at 562 (stating that the burden of proof is on Armstrong to show that the NSC is an agency under the three-factor test of Meyer). 
the burden should be on the government to demonstrate that the entity is not an agency, particularly when that entity has repeatedly characterized itself as such for convenience's sake. ${ }^{183}$ Otherwise, a plaintiff such as Armstrong can ouly argue that an entity is an agency by inference or by reference to generally-known facts about a unit such as the NSC. Given the mequity of resources in this definitional contest, it is unlikely that a private citizen could ever successfully prove that a unit of government is an agency when that entity steadfastly maintains that it is not.

Finally, contrary to Armstrong VII, the stated purpose of FOIA suggests that docunients possessed by the government should, if at all possible, be made available to the public. ${ }^{184}$ FOIA was enacted ostensibly to bring the workings of government into the antiseptic hight of public view. ${ }^{185}$ The motivation behind the Act was to provide free and clear access for the American public to government-held information. ${ }^{186}$ Despite the fact that the Supreme Court's frequent invocation of the "plam meaning" doctrine $^{187}$ disfavors making assuniptions about Congress' imtentions, plain meaning jurisprudence in the realm of FOIA is clearly deniarcated by the presence of statutory exemptions to disclosure. ${ }^{188}$ Congress intended only those documents which it

183. See supra notes 131-33 and accompanying text.

184. Cf. 5 U.S.C. $\$ 552$ (b) (1994) (stating that "any reasonably segregable portion of a record" exempt under FOIA shall be disclosed pursuant to a FOIA request).

185. See H.R. REP. No. 89-1497, at 11 (1966), reprinted in 1966 U.S.C.C.A.N. 2418, 2429.

186. See id.; see also United States Dep't of Defense v. Federal Labor Relations Auth., 510 U.S. 487, 494 (1994) (recognizing that the main purpose of FOIA is to ensure full agency disclosure); United States Dep't of State v. Ray, 502 U.S. 164, 177-78 (1991) (observing that the central purpose of FOIA is to enforce "the citizens' right to be informed about "what their government is up to"').

187. Plain meaning jurisprudence has developed gradually over the past decade, and in a variety of contexts. See, e.g., Rutledge v. United States, 116 S. Ct. 1241 (1996) (relying on the "plain meaning" of statutory language to determine the meaning of a statute); Huddleston v. United States, 485 U.S. 681, 687-88 (1988) (holding interpretation of Federal Rule of Evidence 404(b) which departed from the "plain language" of the text to be inconsistent with the act's purpose); Bourjaily v. Umited States, 483 U.S. 171, 178 (1987) (holding that "[i]t would be extraordinary to require legislative history to confirm the plain meaning of [a statute]"); Garcia v. Umited States, 469 U.S. 70, 75 (1984) (holding that "only the most extraordinary showing of contrary intentions fron [the legislative history] would justify a limitation on the 'plain meaning' of the statutory language"). But see Tome v. United States, 513 U.S. 150, 160-63 (1995) (placing substantial weight on Advisory Committee Note and common law tradition in interpreting the Federal Rules of Evidence).

188. See supra note 15 and accompanying text. 
deemed best excluded to be kept from public scrutiny; by clear rule, all other documents were to be made available for public perusal. ${ }^{189}$ A simplistic view (but not one witlout a realistic basis) of FOIA is that, if a document falls clearly into an exempt category, it slould not be released; if it does not fall into such a category, it must be disclosed. ${ }^{190}$ The information sought by the appellants in Armstrong VII did not clearly fall into an exempt category.

\section{COUNTERPOINTS TO ARMSTRONG VII IN OTHER FOIA DEVELOPMENTS IN 1996}

While the Armstrong VII decision represented a defeat in the ongoing movement for public access to information, both FOIA's stated purpose and other recent developinents in FOIA law suggest that the Armstrong VII decision is misguided. Armstrong VII, while certainly significant, can also be viewed as anomalous.

Two other cases decided during 1996 suggest that the holding in Armstrong VII restrictimg access to government documents is a spurious one. In Avondale Industries, Inc. v. National Labor Relations Board, ${ }^{191}$ despite the fact that information that the NLRB was required to release could potentially be used for suspect purposes, the court construed FOIA's exemptions narrowly (which is the traditional interpretation) to allow as much information as possible into the liands of the public. ${ }^{122}$ Another court, in DeLorme Publishing Co. v. National Oceanic and Atmospheric Admin., ${ }^{193}$ held that, while the government could delay release of certaim nautical cliarting information, it must make sucli information available at the conclusion of a period of time designated by statute. ${ }^{194}$ In sharp contrast to Armstrong VII, these two significant decisions opened government-held information to public inspection.

189. See 5 U.S.C. § 552(a) (1994) (listing the categories of information that the government must disclose).

190. But cf. discussion of current practice infra note 202 .

191. 90 F.3d 955 (5th Cir. 1996).

192. See id. at $961-62$.

193. 917 F. Supp. 867 (D. Me. 1996).

194. See id. at $870-74$. 


\section{A. The Avondale Case}

In Avondale, the court balanced the individual's right to privacy against "the basic pohcy of opening an agency's action to the hight of public scrutiny,"195 and released government documents instead of retaining thein. ${ }^{196}$ The dispute involved a union election held at a factory (Avondale) in which the National Labor Relations Board (NLRB) participated in a supervisory role. ${ }^{197}$ Following the election, which the union won, Avondale presented to the Acting Regional Director of the NLRB its FOIA claim for access to the voting hists prepared by the NLRB for the election. ${ }^{198}$ The NLRB denied the FOIA request, citing Exemptions $6,7(\mathrm{~A})$, and $7(\mathrm{C}){ }^{199}$

The court began its discussion by contrasting the competing interest of the public to inspect documents of official record ${ }^{200}$ with individual citizens' interest in protecting their privacy. ${ }^{201}$ This balancing of interests must give equal consideration to the individual's right to privacy and to the preservation of the basic purpose of FOIA (opening agency action to pubhic scrutiny). ${ }^{202}$

195. Avondale, 90 F.3d at 959. The Fifth Circuit fell back upon its earlier decision in Halloran v. Veterans Administration, 874 F.2d 315 (5th Cir. 1989), where it held that [B]ecause our focus must be upon whether disclosure serves the general public's interest in governmental affairs, the specific motives of the party making the FOIA request are irrelevant. If the general public has a legitimate, albeit abstract, interest in the requested information such that disclosure is warranted, disclosure must be made despite the fact that the party actually requesting and receiving the information may use it for less-than-lofty purposes.

Conversely, if disclosure of the requested information does not serve the purpose of informing the citizenry about the activities of their government, disclosure will not be warranted even though the public may nonetheless prefer, albeit for other reasons, that the information be released.

Id. at 323.

196. See Avondale, $90 \mathrm{~F} .3 \mathrm{~d}$ at 962.

197. See id. at 956-57.

198. See id. at 957.

199. See id. Exemption 6 allows an agency to retain, without disclosure, personnel or medical files. All parts of Exemption 7 relate to information surrounding law enforcement. See 5 U.S.C. \& 522(b)(7) (1994). For a complete list of exemptions, see supra note 15 and accompanying text.

200. See Avondale, 90 F.3d at 959. The court's opinion refers to "[f]ederal regulations [which] state that[] 'the formal documents constituting the record in a case or proceeding are matters of official record and ... are available to the public for inspection." Id. (quoting 29 C.F.R. § 102.117(b)(1) (1996)).

201. See id. at 960 (citing 5 U.S.C. \& 552(b)(6)).

202. See United States Dep't of Defense v. Federal Labor Relations Auth., 510 U.S. 487, 487 (1994); Department of the Air Force v. Rose, 425 U.S. 352, 372 (1976). 
The NLRB asserted that there was no public interest in the marked voting lists because access to the lists would not contribute to the public's understanding of the operations of the governinent, whicl is the central purpose of FOIA; ${ }^{203}$ rather, the information would at best simply have been a ineans of "nionitoring" the government, and, at worst, a vehicle by which Avondale might draw unfair inferences about the voting einployees and the Board's activities. ${ }^{204}$ Avondale, by contrast, suggested that niere attendance at a government-sponsored election is "a quintessentially public act" quite separate from the content of one's vote. ${ }^{205}$ Avondale further argued that the disclosure of the lists was imdeed a matter of public interest because it would illuminate the NLRB's performance of its duty to conduct representative elections. ${ }^{206}$

203. See Avondale, 90 F.3d at 960 . Recent examinations of FOIA decisions have found, however, that the Supreme Court has been willing to depart from its "plain meaning" jurisprudence in order to construe the statutory exemptions to FOIA in as broad a fashion as possible. See, e.g., Beall, supra note 30, at 1257-58 (observing that the Supreme Court has interpreted FOIA to require only the release of information in "the public interest," rather than all information that otherwise might be disclosable given a strict reading of FOIA's exemptions). This precedent, identified as the "central purpose" doctrine, has at its core the philosophy that FOIA demands release only of those documents which directly concem the government's operations. See Fred H. Cate et al., The Right to Privacy and the Public's Right to Know: The "Central Purpose" of the Freedom of Information Act, 46 ADMIN. L. REv. 41, 67 (1994). This doctrine has served to narrow the field of acceptable FOIA requests that the government must process. According to the "central purpose" doctrine, if information contained in government documents stops short of merely "[opening] to the sharp eye of public scrutiny" the activities of the federal government, the documents need not be released. Department of Justice v. Reporters Comm. for Freedom of the Press, 489 U.S. 749, 774 (1989).

While the "central purpose" doctrine was initiated to protect individuals' privacy, the Armstrong VII case suggests that courts are now willing to go farther to retain information within the government's cloister. See Armstrong VII, 90 F.3d 553, 556 (D.C. Cir. 1996) (holding that NSC documents need not be released because the NSC is not an agency under FOIA). In other words, despite the fact that the NSC documents at issue in Armstrong VII neither implicated the privacy interests of American citizens nor fell under a FOIA exemption, the court held that the information contained in such documents need not be released by the government because the NSC does not meet the dubious new "agency" standard articulated by the court. See id. This development may be conceived, not so much as an expansion of the central purpose doctrine, but as an accretion of authority to the advocates of limited disclosure, whose primary weapon to this point has been the central purpose doctrine.

204. See Avondale, 90 F.3d at 962.

205. See id. at 960 .

206. See id. 
The court found that the information was important under the central purpose of FOIA because it would allow Avondale (a member of the public) "to determine whether the NLRB is properly conducting its elections." 207 The court believed that, in order to prove the voter fraud that Avondale alleged, the company must know who voted. ${ }^{208}$ Surprisingly, the court stated that "disclosure of the marked voting lists will likely enable Avondale to prove such allegations." 209 Consequently, the court held Exemption 6 inapplicable because it found significant "the public's interest in monitoring NLRB sponsored elections" and negligible the privacy mvasion of individual citizens. ${ }^{210}$

207. Id. at 961. Ironically, under this interpretation, the voting lists are exactly the sort of information which FOIA's opponents would want withheld. See, e.g., Alfonse M. D'Amato \& Antonia M. Greenman, The Freedom of Information Act and the CIA: How S. 1235 Will Enhance Our Nation's Security, 9 J. OF LEGIS. 179, 182-83 (1982) (suggesting that a problem with FOIA is that it allows the disclosure of information to the wrong sorts of people). The more traditional, pre-"central purpose doctrine" view is perhaps best summarized by Judge Wald, who has observed that "FOIA, like all basic freedoms, sonietimes hurts the worthy and sometimes helps the unworthy." Patricia M. Wald, The Freedom of Information Act: A Short Case Study in the Perils and Paybacks of Legislating Democratic Values, 33 EMORY L.J. 649, 683 (1984).

208. See Avondale, 90 F.3d at 962 (citing John Doe Agency v. John Doe Corp., 493 U.S. 146, 152 (1989) (holding that "[t]le basic purpose of FOIA is to ensure an informed citizenry, vital to the functioning of a democratic society, needed to clieck against corruption and to liold the governors accountable to the governed")).

209. Id. at 962 (enupliasis added). As an aside, it is difficult to imagine how merely reviewing the lists will "prove" anything. If individuals did pose as others and vote multiple tinies, a tactic that Avondale alleges kept anti-union voters from having their votes tallied, the lists will in no way reveal it. The lists contain only voters' names and addresses, not their photos or other identifying information. See id. at 957 n.1. Consequently, the dispute will likely devolve into a shouting match over whose word is more reliable: the affiants who claim that they were prohibited from voting as a result of this conspiracy versus the keepers of the NLRB's lists, whose documentation indicates that they did in fact vote.

Furthermore, the acquisition of the voter lists would reveal little about whether there actually was voter fraud, for either side could have altered the voter list. Pursuant to a pre-election agreenent between Avondale and the NLRB, both an Avondale observer and a union observer were present to monitor the voting at each zone. See id. at 957 n.2. Thus, the union officials could have altered voting lists to cover up fraud, or Avondale officials could have altered voting lists to fabricate evidence of non-existent voter fraud.

A cynic might argue that Avondale may have invented a conspiracy because of its hostility to the union and that it is in fact seeking to harass pro-union workers and the NLRB by prolonging its cliarges, charges it will never be able to "prove." Indeed, approximately sixty unfair labor practices charges had been filed by the union against Avondale within months after the election and about the tinie that Avondale filed its FOIA request. See id. at 957 n.4.

210. Id. at 962 . The court granted summary judginent against Avondale on its Exemp- 
In Armstrong VII, of course, the government avoided the issue whether the public has an interest in inonitoring the NSC's actions by taking that entity out of FOIA consideration at a threshold level. By changing the NSC's status from that of an agency to that of an advisory body to the President, the D.C. Circuit opened the door for cases like Avondale to be decided differently. Under Armstrong VII, inaterials which were of significant public interest and which were not otherwise exenipt under FOIA, were retained in secret by the government. Had a similar anti-access rationale been applied in Avondale, the NLRB might have retained the information, perhaps under the theory that information requested for suspect purposes should not be made available for inspection. In short, if a court can narrow the reach of FOIA by reconstruing an agency in midstreain, the judiciary might envision innumerable scenarios to restrict the free flow of information.

\section{B. The DeLorme Case}

In another significant 1996 decision, DeLorme Publishing Co. v. National Oceanic and Atmospheric Administration (NOAA), ${ }^{211}$ the court illustrated the principle that while certain information might be restricted from public view for a period of time, when applied properly FOIA assures that all information eventually will be made public. ${ }^{212}$ In DeLorme, the court exempted infornation froin disclosure under FOIA Exemption $3 .{ }^{213}$ The case revolved around NOAA's ${ }^{214}$ cooperative venture with a private partner to produce an electronic nautical charting system. ${ }^{215}$ NOAA collaborated with BSB Electronic Charts between August and November

tion 7 claims because that exemption applies only to law enforcement issues. See id.

211. 917 F. Supp. 867 (D. Me. 1996).

212. See id. at 870 .

213. 5 U.S.C. \& 552(b)(3) (1994). For a complete catalog of exemptions, see supra note 15.

214. NOAA is a subdivision of the Department of Commerce.

215. See DeLorme, 917 F.Supp. at 870 . Such an agreement, known as a cooperative research and development agreement (CRADA), is authorized and indeed encouraged by the Federal Technology Transfer Act (FTTA). See id.; see also 15 U.S.C. $\$ 3710$ a (1994) (allowing federal agencies to permit directors of agency laboratories to enter into cooperative research and development agreements with industrial organizations, nonprofit organizations, individuals and other government agencies). DeLorme was among the firms which expressed an interest in the project, but the government chose BSB Electronic Charts to be its partner. See DeLorme, 917 F. Supp. at 870 . 
1994 in the production of electronically-rendered nautical charts; the DeLorme Publishing Company filed two FOIA requests in November 1994 seeking disclosure of those compilations. ${ }^{216}$ NOAA refused to provide the information. ${ }^{217}$

The court construed a statute, the Federal Technology Transfer Act (FTTA), ${ }^{218}$ under Exemption 3 of FOIA, which permits an agency to withhold records that are "specifically exempted from disclosure by [a] statute" other than FOIA. ${ }^{219}$ The court's opinion was based on the 1989 amendments to the FTTA. ${ }^{220}$ These amendments provide two varieties of protection from disclosure of "commercial... information that is privileged or confidential."221 The first, a so-called "trade secrets" exception, ${ }^{222}$ does not apply here. The second type of protection gives the agency discretion to withhold information for up to five years if it would liave been protected coming from the private partner. 223 Determination of how this discretion will be implemented (if the information is "confidential") depends on two factors: first, whether disclosure will "impair the Government's ability to obtain necessary information im the future[;]" or, second, whether disclosure will "cause substantial harm to the competitive position of the person from whom the information was obtained."224 A second,

216. See DeLorme, 917 F. Supp. at 870.

217. See id.

218. See Federal Technology Transfer Act of 1986, Pub. L. No. 99-502, 100 Stat. $1785,1785-97$ (codified in scattered sections of 15 U.S.C.).

219. 5 U.S.C. \& 552(b)(3) (1994). However, to satisfy Exemption 3, the statute must, "(A) require[] that the matters be withheld from the public in such a manner as to leave no discretion on the issue, or (B) establish[] particular criteria for withholding or refer[] to particular types of matters to be withheld." Id.

220. See 15 U.S.C. $\& 3710 \mathrm{a}(\mathrm{c})(7)$ (1994). Congress initially intended the FTTA "to improve the transfer of commercially useful technologies from the Federal laboratories and into the private sector," thereby strengthening the United States both militarily and economically. S. REP. No. 99-283, at 1 (1986), reprinted in 1986 U.S.C.C.A.N. 3442, $3442-43$.

221. 15 U.S.C. $\S 3710 \mathrm{a}(\mathrm{c})(7)(\mathrm{A})(1994)$.

222. The "trade secrets" exception prohibits a federal agency from disclosing such information if it "is obtained in the conduct of research or as a result of activities under ... [the FTTA] from a non-Federal party participating in a cooperative research and development agreement [CRADA]." Id.

223. See id. $\S 3710 \mathrm{a}(\mathrm{c})(7)(B)$. Congress authorized this protection because "the threat of disclosure under [FOIA] of commercial information, developed under the CRADA or otherwise, has been the biggest reason to date for companies declining to enter CRADAs." H.R. CONF. REP. No. 101-331, at 761 (1989), reprinted in 1989 U.S.C.C.A.N. 977, 1150.

224. DeLorme Publ'g Co. v. National Oceanic and Atmospheric Admin., 917 F. Supp. 
potentially more restrictive test has been adopted recently by the D.C. Circuit. ${ }^{225}$ This test holds that commercial information provided to the government is confidential "if it is of a kind that would customarily not be released to the public" by the submitter. ${ }^{226}$ Here, the court found that the result would be the same, simce mapping companies do not customarily release their computer databases to the public. ${ }^{227}$

Nonetheless, the results of the compilation will be made available to the public, albeit somewhat later than DeLorme would have wished. Significantly, the information will be protected and stored in pristine form for the years that the FTTA allows it to be suppressed, as those are the requirements of FOIA. ${ }^{228}$ It bears repeating that the NSC's documents, under the new regime established by the Clinton administration and endorsed by the D.C. Circuit, may be corrupted or only partially protected by the PRA, ${ }^{229}$ since FOIA no longer applies to those documents.

\section{New Legislation}

On October 2, 1996, the Clinton administration endorsed bipartisan legislation updating FOIA to keep pace with technology. ${ }^{230}$ This legislation codifies the decision in Armstrong III that government records kept electromically are subject to disclosure under the Federal Records Act, and by implication, FOlA. ${ }^{231}$ The new act requires agencies to make a concerted effort to provide records in a requested format whenever possible and directs agencies to increase on-line access to government records. ${ }^{232}$

867, 873-74 (D. Me. 1996) (internal quotation marks and citations omitted).

225. See Critical Mass Energy Project v. Nuclear Regulatory Comm'n, 975 F.2d 871, 879 (D.C. Cir. 1992).

226. Id.

227. See DeLorme, 917 F. Supp. at 874 n.6.

228. See 5 U.S.C. \& 552(a) (1994).

229. See supra note 55 and accompanying text.

230. See Statement by William J. Clinton upon signing H.R. 3802, reprinted in 1996 U.S.C.C.A.N. 3477, 3478. The legislation, the Electronic Freedom of Information Act Amendments of 1996, Pub. L. No. 104-231, amended several sections of the Freedom of Information Act, 5 U.S.C.A. $\$ 552$ (West Supp. 1997).

231. See Armstrong III, 810 F. Supp. 335, 340-42 (D.D.C. 1993) (holding that certain electronically stored NSC documents were records subject to disclosure under the Federal Records Act); see also text accompanying notes 21-24.

232. See 5 U.S.C.A. $\$ 552(a)(3)(6)$ (West Supp. 1997) (requiring agencies to provide records in any form requested if the record is readily producible in that form); Id. § 552(a)(2)(7) (requiring agencies to make records created on or after Nov. 1, 1996 avail- 
Ironically, this legislation will not apply to the NSC, whose docuinents will not be free for uncensored inspection after the Armstrong VII decision.

\section{CONCLUSION}

Public access to information about the government took a decided turn for the worse in $1996 .{ }^{233}$ The D.C. Circuit provided the government with a loophole when it held that the National Security Council is not an agency for FOIA purposes. In June 1997, the Supreme Court denied Armstrong's petition for certiora$r i$, effectively bringing to an end this eight-year struggle to pry important historical documents away from the NSC. ${ }^{234}$ Indeed, the Court's summary affirmance of Armstrong VII means that, by now, many Iran-Contra documents could have already been destroyed.

The Armstrong VII decision almost legitimizes the secretive activities of Colonel North and Fawn Hall, smce the decision means that the documents they destroyed would not have been subject to public inspection after all. Armstrong VII permits the NSC to hide documents forever that might have shed light on the Iran-Contra affair. After Armstrong VII, mucl information concerning the workings of government, especially in the areas of national security and defense policy, may never come into the public view.

able by electronic means).

233. On October 11, 1996, the D.C. Circuit again denied Amstrong's request for documents on other grounds. See Amstrong v. Executive Office of the President, 97 F.3d 575, 577 (D.C. Cir. 1996) (holding that the District Court did not err by failing to review certain document requests in camera).

234. See Armstrong v. Executive Office of the President, 117 S. Ct. 1842 (1997). 
$\cdots$ 